Acta Theriologica, Suppl. 5: 9-34, 1998.

PL ISSN 0001-7051

\title{
Genotypic and phenotypic divergence of rodents (Acomys cahirinus and Apodemus mystacinus) at "Evolution Canyon": Micro- and macroscale parallelism
}

\author{
Eviatar NEVO, Gracia M. FILIPPUCCI, Tomas PAVLICEK, Olga GORLOVA, \\ Georgy SHENBROT, Elena IVANITSKAYA and Avigdor BEILES
}

Nevo E., Filippucci G. M., Pavlicek T., Gorlova O., Shenbrot G., Ivanitskaya E. and Beiles A. 1998. Genotypic and phenotypic divergence of rodents (Acomys cahirinus and Apodemus mystacinus) at "Evolution Canyon": Micro- and macroscale parallelism. [In: Ecological genetics in mammals III. G. B. Hartl and J. Markowski, eds]. Acta Theriologica, Suppl. 5: 9-34.

Genetic allozyme and RAPD diversities were examined for ecological-genetic patterns in two rodents, the spiny-mouse Acomys cahirinus (Desmarest, 1819) and woodmouse Apodemus mystacinus (Danford and Alston, 1877), from the ecologically contrasting opposite slopes of the Lower Nahal Oren microsite, Mt. Carmel, Israel, designated by us "Evolution Canyon". Likewise, morphological measurements were compared. Samples of both rodent species were collected from six stations: 3 (upper, middle and lower) on the "tropical" xeric South-facing slope (SFS) and 3 on the opposite "temperate" mesic North-facing slope (NFS) which vary dramatically physically and biotically. Higher solar radiation on the SFS than on the NFS makes it warmer, drier, spatiotemporally more heterogeneous and climatically more fluctuating and stressful than the cooler and more humid NFS. Consequently, the SFS exhibits an open park forest representing an "African" savanna landscape, in sharp contrast with the "European" lush liveoak maquis forest. Inter- and intraslope allozyme, RAPD, and morphological divergence was found in both rodents. Local variation in solar radiation, temperature and aridity stress caused interslope and intraslope adaptive genotypic (proteins and DNA) and phenotypic (morphological, physiological and behavioural) differences paralleling regional patterns across Israel in Acomys and in northern and central Israel in Apodemus. This suggests that, at both the micro- and macroscales, diversifying natural (microclimate) selection appears to be the major evolutionary driving force causing inter- and primarily SFS intraslope adaptive genotypic and phenotypic divergence. "Evolution Canyon" proved in small rodents, as previously in other organisms, an optimal model for unravelling evolution in action across life and organization.

Institute of Evolution, University of Haifa, Mt. Carmel, Haifa 31905, Israel, e-mail: e.nevo@uvm.haifa.ac.il (EN, TP, OG, EI, AB); Dipartimento di Biologia, II Universita di Roma "Tor Vergata", Roma, Italy (GMF); Ramon Science Centre, Ben-Gurion University of the Negev, Mitzpe Ramon 80600, Israel (GS)

Key words: genetic diversity, spiny mouse, woodmouse, adaptation, natural selection 


\section{Contents}

$\begin{array}{ll}\text { Introduction } & 10\end{array}$

"Evolution Canyon" 11

The predominant rodents at "Evolution Canyon" 11

The ecological-genetics of rodents at "Evolution Canyon": The problem of local versus 13 regional divergence

Problems investigated at "Evolution Canyon" $\quad 14$

Material and methods $\quad 14$

$\begin{array}{ll}\text { Ecological background } & 14\end{array}$

Sampling and analysis $\quad 14$

Results

Morphological variation $\quad 18$

$\begin{array}{lr}\text { Genetic diversity } & 18\end{array}$

$\begin{array}{lr}\text { Acomys cahirinus } & 18\end{array}$

$\begin{array}{ll}\text { Allozymic variation } & 18\end{array}$

RAPD diversity $\quad 21$

Apodemus mystacinus $\quad 24$

Allozymic variation $\quad 24$

RAPD diversity $\quad 26$

Discussion 26

"Evolution Canyon": the model background $\quad 26$

The local genetical, morphological, physiological and behavioural patterns 26

The regional morphological, physiological, behavioural, and genetic patterns $\quad 27$

$\begin{array}{ll}\text { Acomys cahirinus } & 27\end{array}$

Apodemus mystacinus $\quad 29$

The evolutionary driving forces causing genotypic and phenotypic divergence of rodents at 31

"Evolution Canyon"

References

\section{Introduction}

Microgeographical studies provide powerful tools to evaluate the relative importance of the forces driving evolution, particularly if they parallel macrogeographic patterns (eg Nevo 1995, 1997). In particular, microscale studies could assess the relative roles of migration and natural selection in moulding the genetic structure of populations at both the genotypic and phenotypic levels. While phenotypic divergence is usually attributed to Darwinian selection, genotypic divergence is still considered by some as neutral (Kimura 1983) or nearly neutral (Ohta and Tachida 1990) rather then largely selective (Nevo 1988, 1998). Our long term research program of genetic diversity in natural populations involved both macro- and microscale studies (Nevo 1978, 1988, 1990, 1995, 1997, 1998, Nevo et al. 1984, 1996, 1998). These studies suggested that natural selection in its various forms appear to be a major differentiating and orienting force of evolutionary change in both genotypes (proteins and DNA) and phenotypes (morphology, physiology and behaviour). 
Recently, we embarked upon a microsite research program designated by us "Evolution Canyon" at Lower Nahal Oren, Mt. Carmel, Israel (Nevo 1994, 1995, 1997) attempting to explore some major unresolved problems of evolutionary biology.

\section{"Evolution Canyon"}

"Evolution Canyon" ( $32^{\circ} 43^{\prime} \mathrm{N}$; $34^{\circ} 58^{\prime} \mathrm{E}$ ) is a Plio-Pleistocene canyon presumably $3-5$ million years ago (Ma). It is eroded in tectonically uplifted Upper Cenomanian limestones (Karcz 1959) geologically identical on the opposite slopes in a regional Mediterranean climate (Atlas of Israel 1970). However, the opposite slopes, separated by only $100 \mathrm{~m}$ (at bottom) and $400 \mathrm{~m}$ (at top), represent dramatic physical and biotic contrasts and divergence due to the higher (up to $300 \%$ ) solar radiation on the South-facing slope (SFS) (H. Kutiel and G. Sher, unpubl.). The SFS is therefore warmer, drier, microclimatically more fluctuating and less predictable than the North-facing slope (NFS), as is true for valleys north of the equator (Cottle 1932). Spatiotemporally, the SFS represents a "broader-niche" (Van Valen 1965), tropical, dry savanna-like biota. The SFS consists spatially of more microhabitat patches and subdivisions than the NFS, involving a mosaic of habitats, comprising of open park forest, savanna plant formations and bushy islands. Notably, small variations in aridity in the savanna-like habitats amplify the biotic divergence on the SFS, both in space and over time. In particular, the lower third of the SFS obtains the runoff, hence is covered by more vegetation and is less expossed to solar radiation, heat and drought. By contrast, the milder and more homogeneous NFS consists of lush and dense liveoak maquis forest with a few island openings (Fig. 1). The sharply contrasting physical and biotic interand intraslope differences provide an ideal model for studying the interaction of population ecology, genetics and evolution in action [Nevo 1995, 1997; Israel Journal of Zoology 42 (4), 1996].

\section{The predominant rodents at "Evolution Canyon"}

Out of the 8 rodent species at "Evolution Canyon" (Blaustein et al, 1996) the two predominant species are African Acomys cahirinus (Desmarest, 1819) and southeast European and Levantine Apodemus mystacinus (Danford and Alston, 1877). Our rodent survey at "Evolution Canyon" (Broza and Nevo 1994, Blaustein et al. 1996) revealed the predominance of African derivative A. cahirinus on the SFS with scarce $A$. mystacinus, and an opposite pattern, ie predominance of European derivative A. mystacinus on the NFS, with scarce A. cahirinus. Because this pattern, ie African versus European derivation of taxa, is true at "Evolution Canyon" across phylogeny (ie in diverse organisms from cyanobacteria to mammals, Nevo 1995, 1997) we designated the SFS as the "African" slope and the NFS as the "European" slope. Clearly, colonizations of AfroAsian versus EuroAsian taxa occur into a generally Mediterranean climate and biota (Nevo 1995, 1997).

Spiny mice of the genus Acomys, are tropical murid rodents (Rodentia, Myomorpha, Muridae) involving about 25 species ranging in Africa and southwest 

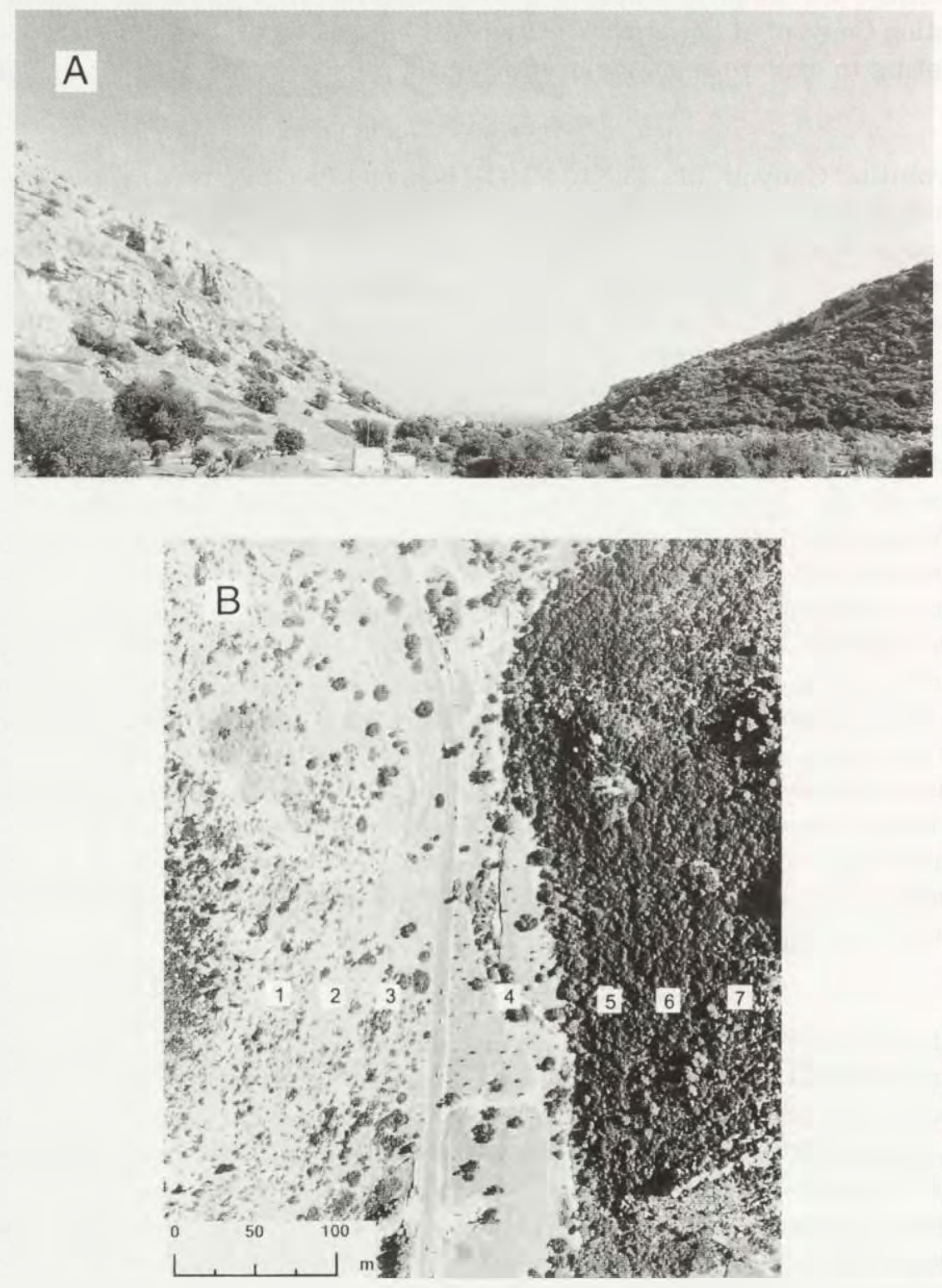

Fig. 1. (A) "Evolution Canyon", Lower Nahal Oren, Mt. Carmel, Israel. Note the plant formations on opposite slopes: the green lush "European" north-facing slope (NFS), sharply contrasting with the open park forest or xeric "African-Asian" savanna on the south-facing slope (SFS).

(B) Air view of "Evolution Canyon". Below the "African" savanna plant formation with an open park forest of Ceratonia siliqua and Pistacia lentiscus on the SFS; Above the south "European" evergreen dense maquis forest of Quercus calliprinos - Pistacia palaestina on the NFS. The 7 stations are indicated: three on the SFS (1-3), on Valley bottom (4) and three on the NFS (5-7). 
Asia in rocky habitats. Two species of spiny mice, the common spiny mouse, $A$. cahirinus, and the golden spiny mouse Acomys russatus, occur in Israel and Sinai (Shkolnik and Borut 1969, Nevo 1989). A. cahirinus is widely distributed across Israel and Sinai ranging in both mesic and xeric environments comprising the Mediterranean, steppe and desert climatic regimes and is thus a climatically euryoek species in range (Fig. 1 in Nevo 1989). However, it lives only in rocky areas, and is therefore relatively stenotopic, or narrow in niche structure. Two chromosome forms of A. cahirinus, which differ by a single Robertsonian change, occur in Israel and Sinai (Wahrman and Goitein 1972; Fig. 1 in Nevo 1989).

The Israeli populations possess $2 \mathrm{n}=38$ chromosomes, and those from Sinai have $2 \mathrm{n}=36$ chromosomes. The two chromosome forms are completely homozygous except for a hybrid zone, about $16 \mathrm{~km}$ long and $15 \mathrm{~km}$ wide, where $2 \mathrm{n}=37$ hybrids were also found. Morphologically, the two karyotypes are indistinguishable, but they have not as yet reached complete reproductive isolation. Although designated as the northern or "Israeli Form" and southern or "Sinaitic Form" (Wahrman and Goitein 1972) they may be viewed, owing to their chromosomal homozygosity across vast ranges, as derivatives of a relatively recent event of speciation, displaying currently its final stages (Nevo 1985). The fossil record indicates that A. cahirinus is an Upper Paleolithic colonizer from the southern deserts into humid Mediterranean Israel, ie, it presumably appeared some 20000 years ago (Tchernov 1968). Therefore, its phenotypic differentiation in Israel is relatively recent, rapid and traceable over time.

The Palearctic genus Apodemus is represented in Europe by five species: $A$. agrarius, belonging to the subgenus Apodemus; A. flavicollis, A. sylvaticus, A. microps, and A. mystacinus, belonging to the subgenus Sylvaemus. A. mystacinus ranges in the Balkan Peninsula, Anatolia and the Near East and can be clearly distinguished from the other three species of the subgenus Sylvaemus. For this reason $A$. mystacinus was recently considered as belonging to a separate subgenus: Karstomys (Filippucci et al. 1989). Apodemus colonized Israel from the north in the early Pleistocene and the succession record of Apodemus fossils in Israel appears in Tchernov (1968:65). A. mystacinus becomes dominant in the Levallois-Mousterian Upper Pleistocene, emerging in the Oumm Qatafa cave 160000 years ago. At "Evolution Canyon" A. mystacinus was described from the Um Usba Mousterian cave 40-50000 years ago (Tchernov 1968).

The ecological-genetics of rodents at "Evolution Canyon": The problem of local versus regional divergence

Here we asked the question whether at "Evolution Canyon" the intraspecific population genetic pattern of Acomys cahirinus and Apodemus mystacinus show inter- and intraslope phenotypic and genotypic divergence in accordance with the dramatic physical and biotic divergence between and within the slopes. Likewise, whether the local microclimatic divergence (Nevo 1995, 1997) parallels the regional macroclimatic one (for the regional perspective of Acomys and Apodemus see Nevo 
1985 and Filippucci et al. 1989, respectively). Our results indeed reflect local genetic divergence largely paralleling the regional macroclimatic mesic-xeric genetic and phenotypic (morphological and physiological) divergence across Israel. This local-regional parallelism in Acomys and Apodemus suggests that climatic natural selection, primarily the aridity stress, is a major evolutionary driving force shaping population genotypic and phenotypic structures.

\section{Problems investigated at "Evolution Canyon"}

At the "Evolution Canyon" model we explore among others, the following problems: What is the relative importance of the forces driving evolution? What is the relative role of neutrality and deterministic factors in genetic population structure and differentiation? Can one demonstrate convergent evolutionary patterns at the molecular and organismic levels across different taxa, ie, across phylogeny, caused by shared environmental stresses? Does the local microscale divergence parallel macroscale patterns, thereby highlighting the causal factors of divergence? Our attempt to answer these and other problems is interdisciplinary and covers microorganisms, fungi, plants (lower and higher) and animals (invertebrates and vertebrates), at both the genotypic (molecular) and phenotypic (organismal) levels (Nevo 1995, 1997). Here we present the first interslope genotypic and phenotypic divergence in two murid rodents, the spiny mouse Acomys cahirinus, and the woodmouse Apodemus mystacinus, henceforward referred to as Acomys and Apodemus.

\section{Material and methods}

\section{Ecological background}

The sharp physical and biotic contrast (Nevo 1995) of the opposite SFS and NFS is seen in Fig. 1a, b. The highly solar radiated SFS is warmer and drier than the NFS. Consequently, the steep SFS (dip $-35^{\circ}$ ) displays an open park forest of Ceratonia siliqua - Pistacia lentiscus with savanna grassland on a very rocky and stony background, a perfect tropical habitat for Acomys. By contrast, the less steep NFS (dip 25") displays a dense maquis forest of Quercus calliprinos and Pistacia palaestina, with much less rocky background excepting the NFS cliff, a perfect habitat for Apodemus. Hence, the opposite slopes harbour African versus European rodent representatives. The small subpopulations of Acomys on the NFS and Apodemus on the SFS both face harsh stressful habitat on a very short geographic distance. This microscale pattern resembles the distribution near each species boundaries.

\section{Sampling and analysis}

Sampling allozymic diversity. We trapped altogether 172 mice of both species at "Evolution Canyon" including 1995/96 captures (Table 1). We analyzed for allozyme diversity 83 mice from "Evolution Canyon", Lower Nahal Oren, Mt. Carmel, Israel, one km upstream from the 6 permanent sampling stations described in Nevo (1995). The allozymic analysis included 33 spiny mice, Acomys, and 50 woodmice, Apodemus, sampled on the opposite slopes, South-facing slope (SFS) and North-facing slope (NFS) at 5 and 6 stations, respectively, as shown in Table 1 . The 6 stations involved 3 on the SFS (Upper, middle and lower, 1-3) and 3 on the NFS (Lower, middle and upper, 5-7). The lower, middle and upper stations on each slope were at 60,90 and $120 \mathrm{~m}$ above sea level. The interslope distance at the valley bottom is $100 \mathrm{~m}$, and at top valley $400 \mathrm{~m}$. 
Table 1. I. Sampling data and molecular (allozyme and RAPD) analysis and II. Morphological body measurements of A. Acomys cahirinus and B. Apodemus mystacinus from 6 stations on two opposite slopes of "Evolution Canyon" in Lower Nahal Oren, Mt. Carmel, Israel. SFS - South-facing slope, NFS - North-facing slope. Weight in grams and length in milimeters. The values: average $\pm \mathrm{SE}$ and in parenthesis relative length to weight. $\mathrm{W}$ - weight, $\mathrm{HBL}$ - body + head length, TL - tail length, HFL - hind foot length, EL - ear length.

I. Sampling data

\begin{tabular}{|c|c|c|c|c|c|c|c|c|c|}
\hline & 1 & 2 & 3 & 5 & 6 & 7 & SFS & NFS & Total \\
\hline \multicolumn{10}{|c|}{ A. Acomys cahirinus } \\
\hline Collected & 16 & 22 & 10 & 1 & 10 & 8 & 54 & 19 & 73 \\
\hline Allozyme analysis & 7 & 10 & 7 & 0 & 5 & 4 & 24 & 9 & 33 \\
\hline DNA RAPD analysis & 3 & 5 & 5 & 0 & 4 & 4 & 13 & 8 & 21 \\
\hline Animals whose station is unknown & & & & & & & 6 & & 6 \\
\hline \multicolumn{10}{|c|}{ B. Apodemus mystacinus } \\
\hline Collected & 15 & 14 & 9 & 19 & 17 & 21 & 39 & 60 & 99 \\
\hline Allozyme analysis & 8 & 7 & 4 & 13 & 10 & 8 & 19 & 31 & 50 \\
\hline DNA RAPD analysis & 4 & 4 & 4 & 6 & 7 & 3 & 12 & 16 & 28 \\
\hline Animals whose station is unknown & & & & & & & 1 & 3 & 4 \\
\hline Grand total (collected) & 31 & 36 & 19 & 20 & 27 & 29 & 93 & 79 & 172 \\
\hline
\end{tabular}

II. Morphology

(1) Slopes

\begin{tabular}{|c|c|c|c|c|c|c|c|}
\hline Sex & $\begin{array}{l}\text { Slope } \\
\text { facing }\end{array}$ & $n$ & W & HBL & $\mathrm{TL}$ & HFL & EL \\
\hline \multicolumn{8}{|c|}{ A. Acomys cahirinus } \\
\hline \multirow[t]{2}{*}{ Males } & SFS & 28 & $46.98 \pm 1.33$ & $\begin{array}{c}113.36 \pm 1.36 \\
(2.413)\end{array}$ & $\begin{array}{c}100.32 \pm 1.66 \\
(2.135)\end{array}$ & $\begin{array}{c}19.75 \pm 0.16 \\
(0.420)\end{array}$ & $\begin{array}{c}19.50 \pm 0.15 \\
\quad(0.415)\end{array}$ \\
\hline & NFS & 10 & $49.86 \pm 1.94$ & $\begin{array}{c}113.60 \pm 2.16 \\
(2.278)\end{array}$ & $\begin{array}{c}104.50 \pm 3.02 \\
(2.096)\end{array}$ & $\begin{array}{c}19.60 \pm 0.28 \\
(0.393)\end{array}$ & $\begin{array}{c}19.80 \pm 0.20 \\
(0.397)\end{array}$ \\
\hline \multirow[t]{2}{*}{ Females } & SFS & 18 & $40.94 \pm 2.32$ & $\begin{array}{c}107.24 \pm 1.74 \\
(2.619)\end{array}$ & $\begin{array}{c}97.00 \pm 2.41 \\
(2.369)\end{array}$ & $\begin{array}{c}19.08 \pm 0.28 \\
(0.466)\end{array}$ & $\begin{array}{c}19.03 \pm 0.35 \\
\quad(0.465)\end{array}$ \\
\hline & NFS & 9 & $42.78 \pm 2.88$ & $\begin{array}{c}106.67 \pm 3.61 \\
(2.493)\end{array}$ & $\begin{array}{c}100.13 \pm 4.10 \\
(2.341)\end{array}$ & $\begin{array}{c}18.78 \pm 0.40 \\
(0.439)\end{array}$ & $\begin{array}{l}19.00 \pm 0.47 \\
\quad(0.444)\end{array}$ \\
\hline \multicolumn{8}{|c|}{ B. Apodemus mystacinus } \\
\hline \multirow[t]{2}{*}{ Males } & SFS & 20 & $39.68 \pm 1.79$ & $\begin{array}{c}111.00 \pm 1.85 \\
(2.797)\end{array}$ & $\begin{array}{c}120.47 \pm 2.33 \\
\quad(3.036)\end{array}$ & $\begin{array}{c}25.28 \pm 0.22 \\
(0.637)\end{array}$ & $\begin{array}{c}19.40 \pm 0.24 \\
\quad(0.489)\end{array}$ \\
\hline & NFS & 33 & $33.14 \pm 1.42$ & $\begin{array}{c}109.95 \pm 1.69 \\
(3.318)\end{array}$ & $\begin{array}{c}115.12 \pm 1.73 \\
(3.474)\end{array}$ & $\begin{array}{c}25.70 \pm 0.17 \\
(0.775)\end{array}$ & $\begin{array}{c}19.33 \pm 0.29 \\
\quad(0.583)\end{array}$ \\
\hline \multirow[t]{2}{*}{ Females } & SFS & 18 & $30.78 \pm 1.45$ & $\begin{array}{c}103.72 \pm 1.76 \\
(3.370)\end{array}$ & $\begin{array}{c}116.93 \pm 2.13 \\
(3.799)\end{array}$ & $\begin{array}{c}25.25 \pm 0.18 \\
(0.820)\end{array}$ & $\begin{array}{c}19.33 \pm 0.24 \\
(0.628)\end{array}$ \\
\hline & NFS & 24 & $37.71 \pm 1.42$ & $\begin{array}{c}107.83 \pm 1.69 \\
(2.859)\end{array}$ & $\begin{array}{c}116.00 \pm 1.73 \\
(3.076)\end{array}$ & $\begin{array}{c}25.42 \pm 0.17 \\
(0.674)\end{array}$ & $\begin{array}{c}19.42 \pm 0.29 \\
\quad(0.515)\end{array}$ \\
\hline
\end{tabular}


(2) Stations

\begin{tabular}{|c|c|c|c|c|c|c|c|}
\hline Sex & $\begin{array}{l}\text { Slope } \\
\text { facing }\end{array}$ & $n$ & W & HBL & TL & $\mathrm{HFL}$ & EL \\
\hline \multicolumn{8}{|c|}{ A. Acomys cahirinus } \\
\hline \multirow[t]{6}{*}{ Males } & S1 & 10 & $46.71 \pm 1.69$ & $\begin{array}{c}113.10 \pm 2.64 \\
(2.421)\end{array}$ & $\begin{array}{c}99.17 \pm 4.75 \\
(2.123)\end{array}$ & $\begin{array}{c}19.75 \pm 0.29 \\
(0.423)\end{array}$ & $\begin{array}{c}19.30 \pm 0.26 \\
(0.413)\end{array}$ \\
\hline & S2 & 14 & $46.25 \pm 1.61$ & $\begin{array}{c}113.64 \pm 2.01 \\
(2.457)\end{array}$ & $\begin{array}{c}100.62 \pm 1.85 \\
(2.175)\end{array}$ & $\begin{array}{c}19.75 \pm 0.22 \\
(0.427)\end{array}$ & $\begin{array}{c}19.57 \pm 0.20 \\
(0.423)\end{array}$ \\
\hline & $\mathrm{S} 3$ & 3 & $49.10 \pm 3.78$ & $\begin{array}{c}111.67 \pm 1.67 \\
(2.274)\end{array}$ & $\begin{array}{c}100.50 \pm 4.50 \\
(2.047)\end{array}$ & $\begin{array}{c}20.00 \pm 0.58 \\
(0.407)\end{array}$ & $\begin{array}{c}20.00 \pm 0.58 \\
(0.407)\end{array}$ \\
\hline & N5 & 0 & & & & & \\
\hline & N6 & 6 & $48.50 \pm 1.19$ & $\begin{array}{c}114.33 \pm 2.17 \\
(2.357)\end{array}$ & $\begin{array}{c}102.50 \pm 4.33 \\
(2.113)\end{array}$ & $\begin{array}{c}19.67 \pm 0.44 \\
(0.406)\end{array}$ & $\begin{array}{c}20.00 \pm 0.26 \\
(0.412)\end{array}$ \\
\hline & N7 & 4 & $51.90 \pm 4.72$ & $\begin{array}{c}112.50 \pm 4.73 \\
(2.168)\end{array}$ & $\begin{array}{c}108.50 \pm 0.50 \\
(2.091)\end{array}$ & $\begin{array}{c}19.50 \pm 0.29 \\
(0.376)\end{array}$ & $\begin{array}{c}19.50 \pm 0.29 \\
(0.376)\end{array}$ \\
\hline \multirow[t]{7}{*}{ Females } & S1 & 5 & $49.45 \pm 2.86$ & $\begin{array}{c}110.00 \pm 1.58 \\
(2.224)\end{array}$ & $\begin{array}{c}104.00 \pm 0.71 \\
(2.103)\end{array}$ & $\begin{array}{c}19.30 \pm 0.44 \\
(0.390)\end{array}$ & $\begin{array}{c}19.50 \pm 0.39 \\
(0.394)\end{array}$ \\
\hline & $\mathrm{S} 2$ & 6 & $38.45 \pm 3.37$ & $\begin{array}{c}104.20 \pm 3.02 \\
(2.710)\end{array}$ & $\begin{array}{c}95.00 \pm 3.45 \\
(2.471)\end{array}$ & $\begin{array}{c}18.67 \pm 0.61 \\
(0.485)\end{array}$ & $\begin{array}{c}18.00 \pm 0.58 \\
(0.468)\end{array}$ \\
\hline & $\mathrm{S} 3$ & 6 & $35.67 \pm 3.50$ & $\begin{array}{c}106.50 \pm 3.96 \\
(2.986)\end{array}$ & $\begin{array}{c}93.00 \pm 5.99 \\
(2.607)\end{array}$ & $\begin{array}{c}19.50 \pm 0.43 \\
(0.547)\end{array}$ & $\begin{array}{c}19.67 \pm 0.71 \\
(0.551)\end{array}$ \\
\hline & N5 & 1 & 28.38 & $\begin{array}{c}97 \\
(3.428)\end{array}$ & $\begin{array}{c}78 \\
(2.756)\end{array}$ & $\begin{array}{c}19 \\
(0.671)\end{array}$ & $\begin{array}{c}17 \\
(0.601)\end{array}$ \\
\hline & N6 & 4 & $42.20 \pm 4.56$ & $\begin{array}{c}105.00 \pm 5.34 \\
(2.488)\end{array}$ & $\begin{array}{c}99.67 \pm 2.91 \\
(2.362)\end{array}$ & $\begin{array}{c}18.50 \pm 0.65 \\
(0.438)\end{array}$ & $\begin{array}{c}19.00 \pm 0.41 \\
(0.450)\end{array}$ \\
\hline & N7 & 4 & $46.98 \pm 2.34$ & $\begin{array}{c}110.75 \pm 5.96 \\
(2.358)\end{array}$ & $\begin{array}{c}106.00 \pm 4.69 \\
(2.257)\end{array}$ & $\begin{array}{c}19.00 \pm 0.71 \\
(0.404)\end{array}$ & $\begin{array}{c}19.50 \pm 0.87 \\
(0.415)\end{array}$ \\
\hline & \multicolumn{7}{|c|}{ B. Apodemus mystacinus } \\
\hline \multirow[t]{6}{*}{ Males } & S1 & 8 & $39.99 \pm 2.67$ & $\begin{array}{c}111.25 \pm 2.86 \\
(2.782)\end{array}$ & $\begin{array}{c}122.43 \pm 3.05 \\
(3.062)\end{array}$ & $\begin{array}{c}25.13 \pm 0.39 \\
(0.628)\end{array}$ & $\begin{array}{c}19.87 \pm 0.35 \\
(0.497)\end{array}$ \\
\hline & $\mathrm{S} 2$ & 7 & $43.89 \pm 2.33$ & $\begin{array}{c}114.14 \pm 2.93 \\
(2.601)\end{array}$ & $\begin{array}{c}122.71 \pm 3.45 \\
(2.796)\end{array}$ & $\begin{array}{c}25.79 \pm 0.31 \\
(0.588)\end{array}$ & $\begin{array}{c}19.29 \pm 0.42 \\
(0.440)\end{array}$ \\
\hline & S3 & 4 & $30.00 \pm 1.94$ & $\begin{array}{c}102.75 \pm 2.29 \\
(3.425)\end{array}$ & $\begin{array}{c}110.00 \pm 5.02 \\
(3.667)\end{array}$ & $\begin{array}{c}24.50 \pm 0.29 \\
(0.817)\end{array}$ & $\begin{array}{c}18.75 \pm 0.63 \\
(0.625)\end{array}$ \\
\hline & N5 & 13 & $37.68 \pm 1.88$ & $\begin{array}{c}107.50 \pm 1.33 \\
(2.853)\end{array}$ & $\begin{array}{c}113.12 \pm 1.73 \\
(3.002)\end{array}$ & $\begin{array}{c}25.38 \pm 0.30 \\
(0.674)\end{array}$ & $\begin{array}{c}18.85 \pm 0.30 \\
(0.500)\end{array}$ \\
\hline & N6 & 8 & $39.45 \pm 3.17$ & $\begin{array}{c}109.88 \pm 2.63 \\
(2.785)\end{array}$ & $\begin{array}{c}116.20 \pm 1.77 \\
(2.946)\end{array}$ & $\begin{array}{c}25.69 \pm 0.39 \\
(0.651)\end{array}$ & $\begin{array}{c}20.38 \pm 1.00 \\
(0.516)\end{array}$ \\
\hline & N7 & 12 & $37.77 \pm 2.30$ & $\begin{array}{c}112.67 \pm 2.51 \\
(2.983)\end{array}$ & $\begin{array}{c}117.00 \pm 2.29 \\
(3.098)\end{array}$ & $\begin{array}{c}26.04 \pm 0.22 \\
(0.690)\end{array}$ & $\begin{array}{c}19.17 \pm 0.21 \\
(0.508)\end{array}$ \\
\hline \multirow[t]{6}{*}{ Females } & S1 & 7 & $28.81 \pm 2.45$ & $\begin{array}{c}102.57 \pm 3.14 \\
(3.560)\end{array}$ & $\begin{array}{c}114.40 \pm 2.38 \\
(3.971)\end{array}$ & $\begin{array}{l}25.79 \pm 0.21 \\
(0.895)\end{array}$ & $\begin{array}{c}19.57 \pm 0.48 \\
(0.679)\end{array}$ \\
\hline & $\mathrm{S} 2$ & 7 & $34.86 \pm 1.84$ & $\begin{array}{c}107.00 \pm 2.37 \\
(3.069)\end{array}$ & $\begin{array}{c}121.50+4.11 \\
(3.485)\end{array}$ & $\begin{array}{c}24.86 \pm 0.14 \\
(0.713)\end{array}$ & $\begin{array}{c}19.00 \pm 0.22 \\
(0.545)\end{array}$ \\
\hline & $\mathrm{S} 3$ & 4 & $27.10 \pm 2.10$ & $\begin{array}{c}100.00 \pm 3.54 \\
(3.690)\end{array}$ & $\begin{array}{c}113.25 \pm 3.25 \\
(4.179)\end{array}$ & $\begin{array}{c}25.00 \pm 0.58 \\
(0.923)\end{array}$ & $\begin{array}{c}19.50 \pm 0.65 \\
(0.720)\end{array}$ \\
\hline & N5 & 5 & $40.88 \pm 3.92$ & $\begin{array}{c}109.20 \pm 4.03 \\
(2.671)\end{array}$ & $\begin{array}{c}114.25 \pm 3.90 \\
(2.795)\end{array}$ & $\begin{array}{l}25.40 \pm 0.40 \\
(0.621)\end{array}$ & $\begin{array}{c}18.80 \pm 0.80 \\
(0.460)\end{array}$ \\
\hline & N6 & 10 & $36.01 \pm 2.10$ & $\begin{array}{c}105.80 \pm 2.57 \\
(2.938)\end{array}$ & $\begin{array}{c}117.33 \pm 3.04 \\
(3.258)\end{array}$ & $\begin{array}{c}25.45 \pm 0.32 \\
(0.707)\end{array}$ & $\begin{array}{c}19.40 \pm 0.52 \\
(0.539)\end{array}$ \\
\hline & N7 & 9 & $37.84 \pm 2.14$ & $\begin{array}{c}109.33 \pm 2.87 \\
(2.889)\end{array}$ & $\begin{array}{c}115.17 \pm 2.18 \\
(3.043)\end{array}$ & $\begin{array}{c}25.39 \pm 0.20 \\
(0.671)\end{array}$ & $\begin{array}{c}19.78 \pm 0.32 \\
(0.523)\end{array}$ \\
\hline
\end{tabular}


Trapping with Sherman live traps (details in Blaustein et al. 1996) was conducted at the 6 locations during summer (28 June to 14 July), winter (7-22 December) 1994; and January-February 1995 , one kilometer upstream from our permanent transect (Nevo 1995). Trapping results appear in Table 1. Morphological measurements were taken of all trapped animals. Tissues of 83 animals collected in 1994 and 1995 were preserved in the laboratory at $-80^{\circ} \mathrm{C}$ untill processed for protein (allozymes) and DNA (RAPDs) diversities.

Electrophoretic procedure and loci studied. Homogenates for electrophoresis were obtained from portions of muscle and kidney tissues crushed in distilled water. Genetic diversity of structural genes encoding for enzymatic and non-enzymatic proteins was assessed using standard horizontal starch-gel electrophoresis (the procedures were those described by Filippucci et al. 1987, Nevo et al. 1994). All gels were prepared using an $11 \%$ suspension of Connaught hydrolyzed starch.

Homogenates obtained from muscle were processed for the following enzymatic proteins involving 35 and 33 putative gene loci in Acomys and Apodemus, respectively: $\alpha$-glycerophosphate dehydrogenase (E.C. 1.1.1.8; $\alpha$-Gpdh), alcohol dehydrogenase (E.C. 1.1.1.1.; Adh), sorbitol dehydrogenase (E.C. 1.1.1.14; $S d h$ ), lactate dehydrogenase (E.C. 1.1.1.27; $L d h-1$ and $L d h-2$ ), malate dehydrogenase (E.C. 1.1.1.37; $M d h-1$ and $M d h-2$ ), malic enzyme (E.C. 1.1.1.40; $M e-1$ and $M e-2$ ), isocitrate dehydrogenase (E.C. 1.1.1.42; $I d h-1$ and $I d h$-2), 6-phosphogluconate dehydrogenase (E.C. 1.1.1.44; $6 P g d h$ ), glucose6-phosphate dehydrogenase (E.C. 1.1.1.49; G6pdh), glyceraldehyde- 3-phosphate dehydrogenase (E.C. 1.2.1.12; G3pdh), indophenol oxidase (E.C. 1.15.1.1; Ipo-1 and Ipo-2), nucleoside phosphorilase (E.C. 2.4.2.1; $N p$ ), glutamate- oxaloacetate transaminase (E.C. 2.6.2.1.; Got-1 and Got-2), hexokinase (E.C. 2.7.1.1; $H k-1$ and $H k-2$ ), creatine kinase (E.C. 2.7.3.2; Ck), adenylate kinase (E.C. 2.7.4.3; $\mathrm{Adk}$ ), phosphoglucomutase (E.C. 2.5.7.1; Pgm-1 and Pgm-2), esterases (E.C. 3.1.1.1; Est-2, Est-3 and Est-4), aminopeptidase (E.C. 3.4.11; Ap-1, $A p-2$ and $A p-4$ ), leucyl aminopeptidase (E.C. $3.4 .11 ;$ Lap), adenosine deaminase (E.C. 3.5.4.4; Ada), aldolase (E.C. 4.1.2.13; Ald), fumarase (E.C. 4.2.1.2; Fum), mannose phosphate isomerase (E.C. 5.3.1.8; $\mathrm{Mpi}$ ), glucose phosphate isomerase = phosphoglucose isomerase (E.C. 5.3.1.9; Pgi).

Isozymes were numbered in order of decreasing mobility from the most anodal one. Allozymes were designated numerically according to their mobility, relative to the most common allele $(=100)$, $(<100=$ slower mobility; $>100=$ faster mobility $)$ in the reference population for Apodemus mystacinus (Filippucci et al. 1989) and at "Evolution Canyon" for Acomys cahirinus.

Intrapopulational genetic diversity was estimated by the following genetic indices: the mean heterozygosity per locus per individual (observed heterozygosity $-H$ ), gene diversity (equals to expected heterozygosity under panmixia $-H_{\mathrm{e}}$ ), the proportion of polymorphic loci in the population $(P-5 \%$ : a locus is considered polymorphic if the frequency of the most common allele is not greater than 0.99 and 0.95 , respectively), and the average number of alleles per locus $(A)$. The amount of genetic divergence between populations was estimated with the index of standard genetic distance $(D)$ (Nei 1978) and the chord distance (Cavalli-Sforza and Edwards 1967). The statistics was computed by the Biosys-1 (Swofford and Selander 1989).

The high number of loci analyzed, 35 and 33 alozymic loci, and 106 and 81 RAPD loci in Acomys and Apodemus, respectively, compensates for the small sample size of some subpopulations, for Apodemus on the SFS and Acomys on the NFS. Values of heterozygosity and genetic distance are therefore reliable with a reasonable margin of precision (Sarich 1977, Nei 1978, Gorman and Renzi 1979). Nevertheless, we plan additional future sampling and analysis.

RAPD PCR diversity. We also analyzed 21 and 28 individuals of Acomys and of Apodemus for RAPD PCR analysis (Table 1). The RAPD method allows the detection of DNA sequence polymorphisms using single primers of arbitrary sequences across the genome in the polymerase chain reaction (Williams et al. 1990). The method is useful in genetic analysis when the variation in banding pattern represents allelic segregation at independent loci (Clark and Lanigan 1993). Polymorphism is detected as band presence versus absence, and band absence may be caused either by failure to prime a site in some individuals because of nucleotide sequence differences or by insertions or deletions in fragment between two conserved primer sites. We analyzed 106 and 81 bands considered as loci in Acomys and Apodemus, respectively. Following are the technical details: 
DNA isolation and arbitrary primers. High molecular weight genomic DNA was extracted from kidney, following Holland (1983). We selected 10 primers that showed reliably reproduced polymorphisms for Acomys out of 140 10-mer primers of RAPD primer Kit 11x, University of British Columbia: Nos. 306, 323, 333, 337, 350, 363, 371, 405, 408, and 411; and for Apodemus 12 primers were selected from RAPD primer kits (Operon Technologies, Almeda, CA, USA; 11 X University of British Columbia, Canada: A-1 Operon, Nos. 312, 313, 318, 319, 322, 326, 328, 329, 349, 419, and 431. Each primer was dissolved in water to yield the final concentration of DNA $10 \mathrm{mg} / \mathrm{ml}$ and stored at $-20^{\circ} \mathrm{C}$.

PCR and agarose gel electrophoresis. Each amplification reaction $(20 \mu \mathrm{l})$ contained $2 \mu \mathrm{l}$ DNA sample for Acomys and $1 \mu \mathrm{l}$ for Apodemus (10 ng/ $\mu \mathrm{l}), 1.2 \mu \mathrm{l}$ primer $(10 \mathrm{ng} / \mu \mathrm{l}), 2.1 \mu \mathrm{l}$ storage buffer, $1.6 \mu \mathrm{l} \mathrm{MgCl} 2$ (25 mM), $2 \mu \mathrm{l}$ dNTPs ( $1 \mathrm{mM}), 2 \mathrm{ml}$ reaction buffer (10x), $0,1 \mu \mathrm{l}$ enzyme and 9 and $10 \mu \mathrm{l}$ $\mathrm{H}_{2} \mathrm{O}$, for Acomys and Apodemus, respectively. $25 \mu \mathrm{l}$ of light paraffin oil was overlaid on each reaction mixture before starting the reaction. DNA amplification was performed using the Perkin-Elmer DNA thermal cycler programmed for 45 cycles of $1 \mathrm{~min}$ at $94^{\circ} \mathrm{C}$ (denaturation), $1 \mathrm{~min}$ at $37^{\circ} \mathrm{C}$ (primer annealing) and $2 \mathrm{~min}$ at $72^{\circ} \mathrm{C}$ (primer extension) followed by storage at $4^{\circ} \mathrm{C}$ until use. $2 \mu \mathrm{l}$ of gel loading dye solution were added directly to the reaction tubes. Depending on species, a total of $20 \mu \mathrm{l}$ DNA samples were loaded for electrophoresis on $1.2 \%$ agarose gel. DNA fragments were then visualized and photographed under UV light.

Data scoring and statistical analysis. Photographs from ethidium bromide stained agarose gels were used to score the data for RAPD analysis. To estimate gene diversity for RAPDs we used formulas published by Lynch and Milligan (1994). In total, 106 and 81 bands ("loci") were obtained for Acomys and Apodemus, respectively. As recommended by Lynch and Milligan (1994), the genetic analysis was restricted to bands whose observed frequency is less than $1-(3 / \mathrm{N})$, where $\mathrm{N}$ is the sample size. In this analysis we regarded the animals from each slope as a subpopulation (pooled data). After the restriction, 77 relevant bands were selected for Acomys and 33 bands for Apodemus. The results are presented in Table 2.

Beside this estimation, we used another approach to compare the two populations. PCR-phenotype of each animal is described by 106 and 81 bands each of which can be equal to 0 or to 1 for Acomys and Apodemus, respectively (presence or absence of each of the bands). We used the proximities program of the SPSS package (SPSS, 1990) for calculations of the Eucledian distances between localities using the band frequency data. The results of these calculations are presented in Table 3 .

\section{Results}

\section{Morphological variation}

Morphological measurements of Acomys and Apodemus appear in Table 1, II. In general, body weight in both species is smaller on the SFS, except in Apodemus males, where the opposite is true. Extremities (tail, TL, hindfoot, HFL, and ear lengths, EL, relative to body weight) were longer on the SFS than on the NFS except in HFL and EL of Apodemus males. These patterns of body weight and extremities length coroborate the Bergmann and Allen rules, ie displaying positive and negative correlation with latitude, respectively, on a local scale.

\section{Genetic diversity}

(1) Allozymic variation

Acomys cahirinus

Interslope genetic divergence. We tested 24 animals from 3 stations (Nos 1-3) on the SFS and 9 animals from 2 stations (Nos 6 and 7) on NFS (Table 1). Only 
Table 2. Allozyme allele frequencies of polymorphic loci of A. Acomys cahirinus and B. Apodemus mystacinus at "Evolution Canyon", Lower Nahal Oren, Mt. Carmel, Israel. *S and *N means an allele retricted to SFS or NFS, respectively. $n$-sample size, $\mathrm{He}$ - gene diversity. A. 28 monomorphic loci: a-G6pdh, Sdh, Ldh-1,2, Mdh-1,2, Me-2, Idh-1,2, 6Pgdh, G6pdh, G3pdh, Ipo, Np, Got-1,2, Hk-1,2, Adk, Pgm-1,3, Ap-1,2, Lap, Est-4, Ald, Pgi, Adh. B. 25 monomorphic loci: a-G6pdh, Sdh, Ldh-1,2, Mdh-1,2, Idh-1,2, Mpi, G3pdh, Ipo-1,2, Fum, Np, Adh, Got-2, Hk-2, Adk, Pgm-2, Ap-2,4, Ck, Lap, Ald, Pgi.

\begin{tabular}{|c|c|c|c|c|c|c|c|c|c|}
\hline & \multirow{2}{*}{$\begin{array}{r}\text { Slope facing: } \\
\text { Station: }\end{array}$} & \multicolumn{3}{|c|}{ SFS } & \multicolumn{3}{|c|}{ NFS } & \multicolumn{2}{|c|}{ Slopes (pooled data) } \\
\hline \multirow[t]{2}{*}{ Locus } & & $\begin{array}{c}\text { high } \\
1\end{array}$ & $\begin{array}{c}\text { middle } \\
2\end{array}$ & $\begin{array}{c}\text { low } \\
3\end{array}$ & $\begin{array}{c}\text { low } \\
5\end{array}$ & $\begin{array}{c}\text { middle } \\
6\end{array}$ & $\begin{array}{c}\text { high } \\
7\end{array}$ & SFS & NFS \\
\hline & \multicolumn{9}{|c|}{ A. Acomys cahirinus } \\
\hline \multirow[t]{2}{*}{ Ada } & $a$ & 1.000 & 0.850 & 1.000 & - & 1.000 & 1.000 & 0.938 & 1.000 \\
\hline & $b * \mathrm{~S}$ & 0.0 & 0.150 & 0.0 & & 0.0 & 0.0 & 0.063 & 0.0 \\
\hline \multicolumn{2}{|l|}{$\mathrm{He}$} & 0.0 & 0.255 & 0.0 & & 0.0 & 0.0 & 0.116 & 0.0 \\
\hline \multicolumn{2}{|l|}{$n$} & 7 & 10 & 7 & - & 5 & 4 & 24 & 9 \\
\hline \multirow[t]{3}{*}{$M p i$} & $a$ & 0.643 & 0.600 & 0.643 & - & 0.600 & 0.625 & 0.625 & 0.611 \\
\hline & $b$ & 0.071 & 0.050 & 0.071 & & 0.100 & 0.0 & 0.063 & 0.056 \\
\hline & $c$ & 0.286 & 0.350 & 0.286 & & 0.300 & 0.375 & 0.313 & 0.333 \\
\hline \multicolumn{2}{|l|}{$\mathrm{He}$} & 0.500 & 0.515 & 0.500 & & 0.540 & 0.469 & 0.507 & 0.513 \\
\hline \multicolumn{2}{|l|}{$n$} & 7 & 10 & 7 & - & 5 & 4 & 24 & 9 \\
\hline \multirow[t]{3}{*}{$M e-1$} & $a$ & 0.786 & 0.944 & 1.000 & - & 0.800 & 0.500 & 0.913 & 0.667 \\
\hline & $b$ & 0.214 & 0.056 & 0.0 & & 0.200 & 0.250 & 0.087 & 0.222 \\
\hline & $c^{*} \mathrm{~N}$ & 0.0 & 0.0 & 0.0 & & 0.0 & 0.250 & 0.0 & 0.111 \\
\hline \multicolumn{2}{|l|}{$\mathrm{He}$} & 0.336 & 0.106 & 0.0 & & 0.320 & 0.625 & 0.159 & 0.506 \\
\hline \multicolumn{2}{|l|}{$n$} & 7 & 9 & 7 & - & 5 & 4 & 23 & 9 \\
\hline \multirow[t]{3}{*}{$C k$} & $a$ & 0.929 & 0.850 & 1.000 & - & 1.000 & 1.000 & 0.917 & 1.000 \\
\hline & $b^{*} \mathrm{~S}$ & 0.0 & 0.050 & 0.0 & & 0.0 & 0.0 & 0.021 & 0.0 \\
\hline & $c * \mathrm{~S}$ & 0.071 & 0.100 & 0.0 & & 0.0 & 0.0 & 0.063 & 0.0 \\
\hline \multicolumn{2}{|l|}{$\mathrm{He}$} & 0.132 & 0.265 & 0.0 & & 0.0 & 0.0 & 0.155 & 0.0 \\
\hline \multicolumn{2}{|l|}{$n$} & 7 & 10 & 7 & - & 5 & 4 & 24 & 9 \\
\hline \multirow[t]{2}{*}{ Est-2 } & $a$ & 1.000 & 0.750 & 1.000 & - & 0.900 & 0.875 & 0.896 & 0.889 \\
\hline & $b$ & 0.0 & 0.250 & 0.0 & & 0.100 & 0.125 & 0.104 & 0.111 \\
\hline \multicolumn{2}{|l|}{$\mathrm{He}$} & 0.0 & 0.375 & 0.0 & & 0.180 & 0.219 & 0.186 & 0.197 \\
\hline \multicolumn{2}{|l|}{$n$} & 7 & 10 & 7 & - & 5 & 4 & 24 & 9 \\
\hline \multirow[t]{2}{*}{ Est-3 } & $a$ & 0.917 & 0.950 & 1.000 & - & 0.900 & 1.000 & 0.957 & 0.944 \\
\hline & $b$ & 0.083 & 0.050 & 0.0 & & 0.100 & 0.0 & 0.043 & 0.056 \\
\hline \multicolumn{2}{|l|}{$\mathrm{He}$} & 0.152 & 0.095 & 0.0 & & 0.180 & 0.0 & 0.082 & 0.106 \\
\hline \multicolumn{2}{|l|}{$n$} & 6 & 10 & 7 & - & 5 & 4 & 23 & 9 \\
\hline \multirow[t]{2}{*}{ Fum } & $a$ & 0.750 & 0.938 & 1.000 & - & 0.900 & 1.000 & 0.921 & 0.944 \\
\hline & $b$ & 0.250 & 0.063 & 0.0 & & 0.100 & 0.0 & 0.079 & 0.056 \\
\hline \multicolumn{2}{|l|}{$\mathrm{He}$} & 0.375 & 0.116 & 0.0 & & 0.180 & 0.0 & 0.146 & 0.106 \\
\hline \multicolumn{2}{|c|}{$n$} & 4 & 8 & 7 & - & 5 & 4 & 19 & 9 \\
\hline Ave & rage $n$ & 6.4 & 9.6 & 7 & 0 & 5 & 4 & 23 & 9 \\
\hline
\end{tabular}


Table 2 - concluded

\begin{tabular}{|c|c|c|c|c|c|c|c|c|c|}
\hline \multirow{2}{*}{ Locus } & \multirow{2}{*}{$\begin{array}{l}\text { Slope facing: } \\
\text { Station: } \\
\text { Allele }\end{array}$} & \multicolumn{3}{|c|}{ SFS } & \multicolumn{3}{|c|}{ NFS } & \multicolumn{2}{|c|}{ Slopes (pooled data) } \\
\hline & & $\begin{array}{c}\text { high } \\
1\end{array}$ & $\begin{array}{c}\text { middle } \\
2\end{array}$ & $\begin{array}{c}\text { low } \\
3\end{array}$ & $\begin{array}{c}\text { low } \\
5\end{array}$ & $\begin{array}{c}\text { middle } \\
6\end{array}$ & $\begin{array}{c}\text { high } \\
7\end{array}$ & SFS & NFS \\
\hline \multicolumn{10}{|c|}{ B. Apodemus mystacinus } \\
\hline Ada & $a^{*} \mathrm{~N}$ & 0.0 & 0.0 & 0.0 & 0.0 & 0.0 & 0.063 & 0.0 & 0.016 \\
\hline & $b$ & 1.000 & 1.000 & 1.000 & 0.923 & 1.000 & 0.938 & 1.000 & 0.952 \\
\hline & $c * \mathrm{~N}$ & 0.0 & 0.0 & 0.0 & 0.077 & 0.0 & 0.0 & 0.0 & 0.032 \\
\hline $\mathrm{He}$ & & 0.0 & 0.0 & 0.0 & 0.142 & 0.0 & 0.116 & 0.0 & 0.092 \\
\hline \multirow[t]{3}{*}{$\mathrm{Me}-1$} & $a^{*} \mathrm{~N}$ & 0.0 & 0.0 & 0.0 & 0.0 & 0.0 & 0.063 & 0.0 & 0.016 \\
\hline & $b$ & 0.688 & 0.857 & 0.750 & 0.654 & 0.800 & 0.750 & 0.763 & 0.726 \\
\hline & $c$ & 0.313 & 0.143 & 0.250 & 0.346 & 0.200 & 0.188 & 0.237 & 0.258 \\
\hline $\mathrm{He}$ & & 0.429 & 0.245 & 0.375 & 0.453 & 0.320 & 0.398 & 0.362 & 0.406 \\
\hline \multirow[t]{3}{*}{$\mathrm{Me}-2$} & $a^{*} \mathrm{~N}$ & 0.0 & 0.0 & 0.0 & 0.038 & 0.050 & 0.0 & 0.0 & 0.032 \\
\hline & $b$ & 0.500 & 0.857 & 0.625 & 0.885 & 0.950 & 0.750 & 0.658 & 0.871 \\
\hline & $c$ & 0.500 & 0.143 & 0.375 & 0.077 & 0.0 & 0.250 & 0.342 & 0.097 \\
\hline $\mathrm{He}$ & & 0.500 & 0.245 & 0.469 & 0.211 & 0.095 & 0.375 & 0.450 & 0.231 \\
\hline \multirow[t]{3}{*}{ 6Pgdh } & $a^{*} \mathrm{~S}$ & 0.0 & 0.0 & 0.125 & 0.0 & 0.0 & 0.0 & 0.026 & 0.0 \\
\hline & $b$ & 1.000 & 1.000 & 0.875 & 0.923 & 0.850 & 1.000 & 0.974 & 0.919 \\
\hline & $c^{*} \mathrm{~N}$ & 0.0 & 0.0 & 0.0 & 0.077 & 0.150 & 0.0 & 0.0 & 0.081 \\
\hline $\mathrm{He}$ & & 0.0 & 0.0 & 0.219 & 0.142 & 0.255 & 0.0 & 0.051 & 0.149 \\
\hline \multirow[t]{2}{*}{ G6pdh } & $a$ & 1.000 & 0.929 & 1.000 & 0.962 & 1.000 & 1.000 & 0.974 & 0.984 \\
\hline & $b$ & 0.0 & 0.071 & 0.0 & 0.038 & 0.0 & 0.0 & 0.026 & 0.016 \\
\hline $\mathrm{He}$ & & 0.0 & 0.132 & 0.0 & 0.073 & 0.0 & 0.0 & 0.051 & 0.031 \\
\hline \multirow[t]{2}{*}{ Got-1 } & $a$ & 0.875 & 0.929 & 1.000 & 0.846 & 0.900 & 0.938 & 0.921 & 0.887 \\
\hline & $b$ & 0.125 & 0.071 & 0.0 & 0.154 & 0.100 & 0.063 & 0.079 & 0.113 \\
\hline $\mathrm{He}$ & & 0.219 & 0.132 & 0.0 & 0.261 & 0.180 & 0.116 & 0.146 & 0.200 \\
\hline \multirow[t]{3}{*}{ Est-3 } & $a$ & 0.688 & 0.071 & 0.250 & 0.269 & 0.150 & 0.063 & 0.368 & 0.177 \\
\hline & $b$ & 0.313 & 0.929 & 0.750 & 0.692 & 0.850 & 0.938 & 0.632 & 0.806 \\
\hline & $c^{*} \mathrm{~N}$ & 0.0 & 0.0 & 0.0 & 0.038 & 0.0 & 0.0 & 0.0 & 0.016 \\
\hline $\mathrm{He}$ & & 0.152 & 0.132 & 0.375 & 0.447 & 0.255 & 0.116 & 0.465 & 0.319 \\
\hline \multirow[t]{2}{*}{$P g m-1$} & $a$ & 1.000 & 1.000 & 1.000 & 0.962 & 0.950 & 1.000 & 1.000 & 0.968 \\
\hline & $b^{*} \mathrm{~N}$ & 0.0 & 0.0 & 0.0 & 0.038 & 0.050 & 0.0 & 0.0 & 0.032 \\
\hline $\mathrm{He}$ & & 0.0 & 0.0 & 0.0 & 0.073 & 0.095 & 0.0 & 0.0 & 0.062 \\
\hline$n$ & & 8 & 7 & 4 & 13 & 10 & 8 & 19 & 31 \\
\hline
\end{tabular}

one Acomys was caught at station 5 (NFS-low), despite successive trap setting, suggesting that this lower station is an unfit habitat for Acomys, possibly because it is largely rockless. Seven loci out of 35 (20\%) (Me-1, Ck, Ada, Mpi, Fum, Est-2, Est-3) were polymorphic (Table 2). All the 7 loci were polymorphic on SFS and 
only 5 on NFS. Four alleles were slope-specific, one to NFS and 3 to SFS (Table 2). All other loci were monomorphic on both slopes (Adh, $\alpha G p d h, S d h, L d h-1,2$, Mdh-1,2, Me-2, Idh-1,2, 6Pgdh, G-6pdh, G3pdh, Ipo, Got-1,2, Hk-1,2, Adk, Pgm-1,2, Np, Lap, Ap-1,2, Est-4, Ald, Pgi).

Genetic indices. Results appear in Table 3 . The general level of diversity is low. It is obvious that in all indices $(A, P, H$, and $H e$ ) the relatively more mesic and vegetated low station of SFS (S3) had the lowest diversity in Nahal Oren, whereas the more xeric middle station (S2) only $30 \mathrm{~m}$ above had the highest level of diversity, except for $H$, for which the exposed rocky upper station 7 on NFS was more diverse. Thus, genetic intraslope divergence was larger on the ecologically heterogeneous SFS than the interslope divergence.

Comparing the slopes reveals that in A and P SFS shows higher diversity, whereas $H$ and $H e$ are higher on NFS. This contradiction between the $P$ and $H$ estimates may be caused by the extreme drop in $H$ and $H e$ in S3, and the high $H$ and $\mathrm{He}$ of $\mathrm{Me}-1$ in N7 (100\% heterozygotes). Overall, however, if the 2 xeric stations of SFS (Nos 1 and 2) are compared with the 2 mesic stations of NSF (Nos 6 and 7) then the SFS animals are more genetically diverse than the NFS animals (excepting $H$ ), as is also true regionally across Israel (Nevo 1985, and see Discussion).

Genetic distances. Nei's genetic distances were too small to be used here $(D=$ $0.00-0.003$ ). Therefore, we used the Cavalli-Sforza and Edwards (1967) chord distance which appear in Table 4 . The closest stations were S1 and N6 $(=0.051)$, whereas the most distant stations were $\mathrm{S} 1$ or S2 and N7 $(=0.103)$. The average interslope distance is less than the distances between the SFS stations and is equal to the within NFS distance (Table 4).

A dendrogram based on the genetic distance matrix shows that N6 and S1 are the closest subpopulations and then $\mathrm{S} 2, \mathrm{~S} 3$ and N7 are sequentially joining the first pair (Fig. 2).

Gametic phase disequilibria. We found 8 gametic phase disequilibria (D) on the SFS and 6 on NFS with $|\mathrm{D}|>0.010$ (Table 5). No D was significant, presumably because of the small sample sizes. Two pairs showed the same signed D on both slopes, so they can be regarded as general Ds $(M p i \times M e-1$ and $M p i \times E s t-2)$ while the other 10 Ds are presumably slope-specific, 6 on the SFS and 4 on the NFS.

(2) RAPD diversity

Altogether we obtained 106 bands, considered putatively as loci, by using 10 primers as described in Material and methods. The results based on phenotypic band counting appear in Table 3 .

Band counting. Polymorphic band number was higher on the SFS than on NFS (75 versus 72 ). The opposite was true if station $\mathrm{S} 3$ was omitted in order to compare interslope parallel stations, ie, S1 and S2 versus N6 and N7. A gradual decrease of polymorphic band percentage was displayed upward on the SFS from station S3 through S2 to the most xeric S1 (52, 47 and 43, respectively) (Table 3). 


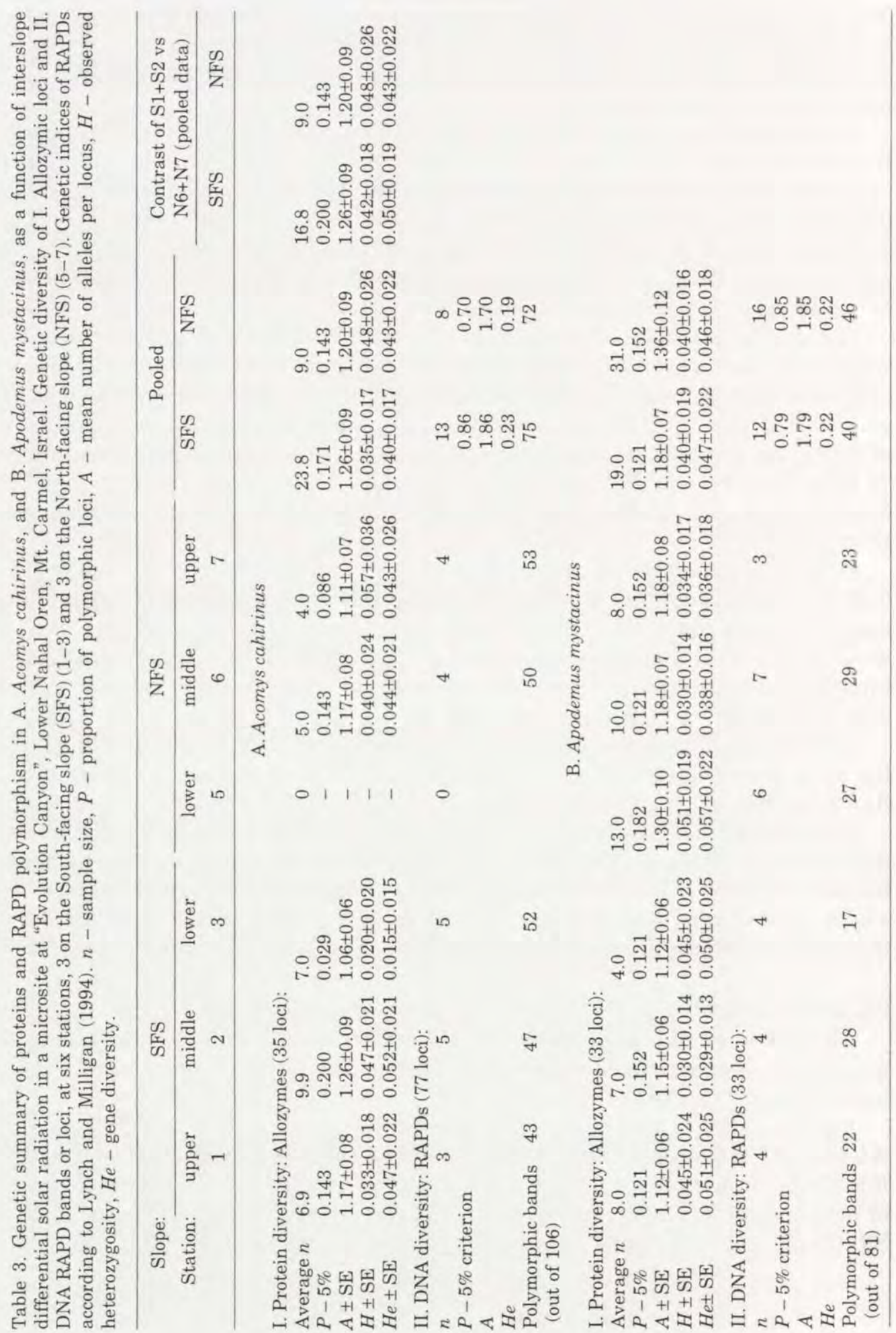


(1) Allozymic variation

We sampled 19 animals from the SFS and 31 animals from the NFS. Among 33 loci, 8 loci $(24 \%)$ were polymorphic. Seven slope-specific alleles were found on the NFS whereas only a single allele was found on the SFS (Table 2B). Presumably, the SFS stress on mesic Apodemus selects for a restricted subset of alleles, adapted to xeric conditions typifying the SFS, as was also shown for Apodemus allozymes regionally (Filippucci et al. 1989) and for other organisms tested experimentally under heavy pollution controlled laboratory experiments (eg Nevo et al. 1981).

Genetic indices. Results appear in Table 3B. The interslope and intraslope differences are milder in Apodemus than in Acomys. The most polymorphic $(P$, also in $H, H e$, and $A$ ) station was N5 (NFS-low), whereas the least polymorphic stations were $\mathrm{S} 1, \mathrm{~S} 3$ and N6. Heterozygosity $(H)$ and genic diversity $(H e)$ were equal on both slopes. In $A$ and $P$ NFS is more diverse than SFS, in contrast to Acomys.

Genetic distance. Nei's genetic distance was again inappropriate. Only S1 was separated from S2, N6 and N7 by D's larger than 0.010. In Cavalli-Sforza and Edwards Chord distance (Table 4B), and in other distance measures, the largest

\section{A. Acomys cahirinus}

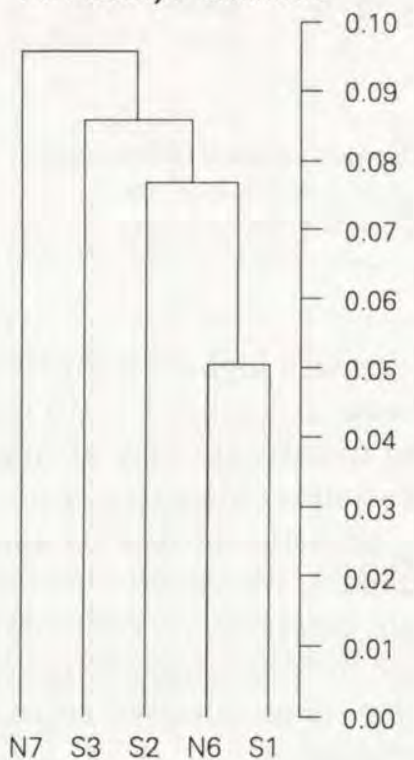

\section{B. Apodemus mystacinus}

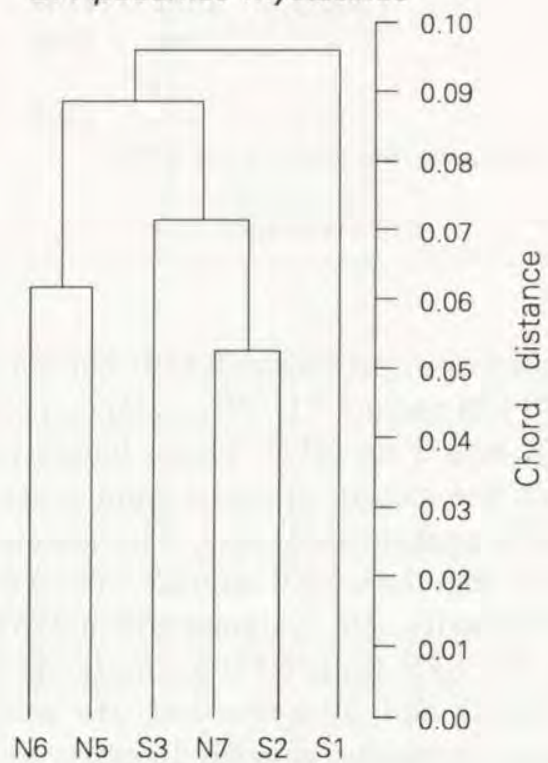

Fig. 2. (A) Dendrogram based on genetic distances between stations calculated from allozymic variation (Table 4) of Acomys cahirinus from 5 stations on the SFS (South upper, S1, South middle, S2, and South low, S3) and NFS (North middle, N6, and North upper, N7). (B) Dendrogram based on genetic distances between station calculated from allozymic variation (Table 4), of Apodemus mystacinus from 3 stations on the SFS (upper, middle, low, S1, S2, S3, respectively) and 3 stations on the NFS (lower, middle and upper, N5, N6, N7). 
distance was between $\mathrm{S} 1$ and N6 (0.120) whereas S2 and N7 were the genetically closest stations (0.053). This is exactly the opposite than in Acomys. Also, in contrast to Acomys, in Apodemus the interslope average distance was larger than the within slope distances $(0.087>0.082$ and 0.080). We used the Cavalli-Sforza and Edwards Chord estimates to construct the dendrogram (Fig. 2B). Three clusters are obvious: $\mathrm{S} 2$ with $\mathrm{N} 7$ and $\mathrm{S} 3$, N5 with N6, and S1 is the farthest subpopultion.

Gametic phase disequilibrium. We found 3 allozyme Ds on the SFS and 4 Ds on NFS with $|\mathrm{D}|>0.010$. Of those, Me-1 $\times$ Est-3 seems to be general while the other disequilibria are slope-specific, 2 on the SFS and 3 on the NFS (Table 5B).

Table 5. Gametic phase disequilibria, absolute (D) and relative ( $\left.\mathrm{D}^{\prime}\right)$, between paired loci of A. Acomys cahirinus and B. Apodemus mystacinus at "Evolution Canyon", Lower Nahal Oren, Mt. Carmel: (1) general (2) specific to NFS and (3) specific to SFS. c - complete association: one gametic type is missing (Clegg et al. 1976).

\begin{tabular}{|c|c|c|c|c|}
\hline \multirow{2}{*}{ Locus and allele } & \multicolumn{2}{|c|}{ NFS } & \multicolumn{2}{|c|}{ SFS } \\
\hline & D & $\left(D^{\prime}\right)$ & D & $\left(D^{\prime}\right)$ \\
\hline \multicolumn{5}{|c|}{ A. Acomys cahirinus } \\
\hline \multicolumn{5}{|l|}{ (1) General disequilibria } \\
\hline$M e-1 a-M p i c$ & 0.040 & $(0.518)$ & 0.019 & $(0.950)$ \\
\hline Est-2a-Mpic & 0.017 & $(0.798)$ & 0.018 & $(0.851)$ \\
\hline \multicolumn{5}{|l|}{ (2) Specific to NFS } \\
\hline Me-1 $a-$ Est $-2 a$ & 0.038 & $(0.818)$ & -0.006 & $(0.931)$ \\
\hline Fuma-Mpic & 0.019 & $(1.0, c)$ & 0.003 & $(0.095)$ \\
\hline Est $-3 a-M e-1 a$ & -0.019 & $(1.0, c)$ & -0.001 & $(0.811)$ \\
\hline Fum $a-M e-1 a$ & -0.019 & $(1,0, c)$ & -0.004 & $(1.0, c)$ \\
\hline \multicolumn{5}{|l|}{ (3) Specific to SFS } \\
\hline Est-2 $a-A d a b$ & - & & -0.038 & $(0.950)$ \\
\hline Fum $a-A d a b$ & - & & -0.020 & $(0.275)$ \\
\hline Est-2a-Fum $a$ & -0.006 & $(1.0, c)$ & 0.016 & $(0.233)$ \\
\hline Est-3a-Mpic & - & & & \\
\hline$A d a b-M p i c$ & - & & -0.013 & $(0.938)$ \\
\hline$C k a-M p i c$ & - & & 0.012 & $(0.856)$ \\
\hline \multicolumn{5}{|c|}{ B. Apodemus mystacinus } \\
\hline (1) General disequilibria & & & & \\
\hline$M e-1 b-E s t-3 b$ & 0.028 & $(0.229)$ & 0.035 & $(0.289)$ \\
\hline \multicolumn{5}{|l|}{ (2) Specific to NFS } \\
\hline Est-3 $b-6 P g d h a$ & 0.017 & $(0.262)$ & - & \\
\hline$P g m-1 a-6 P g d h a$ & 0.014 & $(0.472)$ & - & \\
\hline$M e-1 b-6 P g d h a$ & -0.012 & $(0.896)$ & - & \\
\hline \multicolumn{5}{|l|}{ (3) Specific to SFS } \\
\hline$M e-2 b-E s t-3 b$ & -0.005 & $(0.213)$ & 0.032 & $(0.148)$ \\
\hline Got $-1 a-E s t-3 b$ & 0.006 & $(0.473)$ & -0.019 & $(0.921)$ \\
\hline
\end{tabular}


(2) RAPD diversity

Altogether we obtained 81 bands (= loci) by using 10 primers as described in Material and Methods. The results based on phenotypic band counting appear in Table 3B.

Band counting. Polymorphic band number was higher on the NFS than on the SFS (46 versus 40 ). A decrease of polymorphic band percentage was displayed upward on the NFS (from stations N5 and N6 to the most xeric station on this slope, N7 (27, 29 and 23, respectively), (Table 3B).

Band slope specificity. RAPD band-slope specificity was lower on the SFS than on the NFS ( 5 versus 7 , for $\mathrm{N}=12$ and 16 , respectively).

Band genetic summary. The RAPD genetic indices, calculated according to Lynch and Milligan (1994) equations were based on only 33 bands. The value of $P-5 \%$, and $A$, are higher on the NFS, and $H e$ is equal on both slopes.

Conclusion. The comparison of genetic patterns of both allozymes and RAPDs in Apodemus and Acomys indicated opposite trends in the two rodents. The "xeric", climatically more generalist, Acomys showed more diversity on the warmer and drier SFS, while the mesic, climatically more specialist, Apodemus showed more diversity on the cooler and wetter NSF. Only a subset of the genetic variation of Apodemus persists in the subpopulation hostile SFS. Likewise, except in $H$, the Acomys subpopulations on the NSF display lower genetic diversity (see a parallel case in controlled pollution biology experiments in Nevo et al. 1981). Remarkably, beside a general gametic phase disequilibria, each slope has its unique ensemble of D's.

\section{Discussion}

\section{"Evolution Canyon": the model background}

"Evolution Canyon". The sharp physical and biotic inter- and intraslope contrasts are remarkable: the SFS represents a very heterogeneous dry tropical "African" savanna on a very rocky formation. By contrast, the NFS represents a mesic and cooler temperate "European" lush and dense liveoak maquis forest, with restricted rocky habitats (Fig. 1; Nevo 1995, 1997), except in its cliff. This dramatic biotic contrast derives from the physical climatic interslope divergence. The SFS obtains up to $300 \%$ more solar radiation deduced from computer simulations $(\mathrm{H}$. Kutiel and G. Sher, unpubl.), and partly documented by direct automatic microclimatic measurements around the clock measurements (in preparation). The sharp physical and biotic interslope habitat divergence results in the high predominance of tropical Acomys and temperate Apodemus on the SFS and NFS, respectively (Table 1 ). This local divergence reflects their original regional-global biogeographical origins, African for Acomys and European for Apodemus.

The local genetical, morphological, physiological and behavioural patterns

The inter- and intraslope genetic differences, over a very short geographical transect of $300 \mathrm{~m}$, displayed by both Acomys and Apodemus in multilocus allozyme 
and RAPD polymorphisms, heterozygosity, genic diversity, unique alleles, and gametic phase disequilibria indicate microsite genetic divergent patterns presumably caused by micro-climatic natural selection. The relatively small sample sizes are compensated by the large number of allozyme and RAPD loci, 141 and 114 in Acomys and Apodemus, respectively. Interslope migration is excluded as a major evolutionary factor, since it was not observed in mark-recapture experiments (Blaustein et al. 1996), and factually because of its largely homogenizing effect which can not explain the interslope divergent genetic patterns observed. Morphologically, in general, both rodents (excepting Apodemus males) showed smaller size and longer extermities on the warmer SFS, displaying locally the Bergmann and Allen rules, respectively. Physiological comparison indicated higher activity pattern and metabolism (20\% higher oxygen consumption) in Acomys from the NSF than Acomys from the SFS (A. Haim et al., in prep.).

The local genetic patterns, in both Acomys and Apodemus parallel regional genetic patterns across Israel, ie, higher genetic diversity in local and regional xeric environments in Acomys (Nevo 1985) and lower genetic diversity in local and regional xeric environments for Apodemus (Filippucci et al. 1989). Moreover, the local morphological (Table 1), physiological and behavioural (A. Haim et al, , in prep.) interslope divergent patterns of Acomys parallel the regional morphological (Nevo 1989) and physiological (Weissenberg and Shkolnik 1994) divergent patterns of Acomys mesic-xeric across Israel. The Apodemus morphological results are less clear regionally (Table 2 in Filippucci et al. 1989) probably because the geographical spread of the more specialist Apodemus is restricted in Israel than that of Acomys. Southern Apodemus boundary extends only to the Judean Mountains near Jerusalem, whereas climatically more generalist Acomys ranges across mesic and xeric Israel into the Negev and Sinai. This parallelism between local and regional patterns suggest that the genetic, morphologic and physiologic diversities represent a complex adaptive syndrome contributing to fitness across a gradient of increasing aridity. Climatic natural selection, through aridity and temperature stresses, appears to be the major differentiating factor of this syndrome at both the microand macroscales. Following is an overview of the regional morphological physiological and genetic differentiation of Acomys cahirinus across mesic and xeric Israel, and the morphological and genetic differentiation of Apodemus mystacinus.

The regional morphological, physiological, behavioural, and genetic patterns

Acomys cahirinus

Regional morphological adaptations. The genus Acomys involves 25 species, largely African, and only few species colonized the Near East, Cyprus and Crete. A. cahirinus ranges in Israel in rocky habitats across mesic (Mediterranean) and xeric (steppic, Irano-Turanian, and desert, Saharo-Sindian) environments. Regionally, across Israel, body weight and length decreased, whereas extremities, ie tail, ear and relative forefoot and hind foot lengths generally increased with increasing aridity and temperature southwards into the Negev and Sinai deserts 


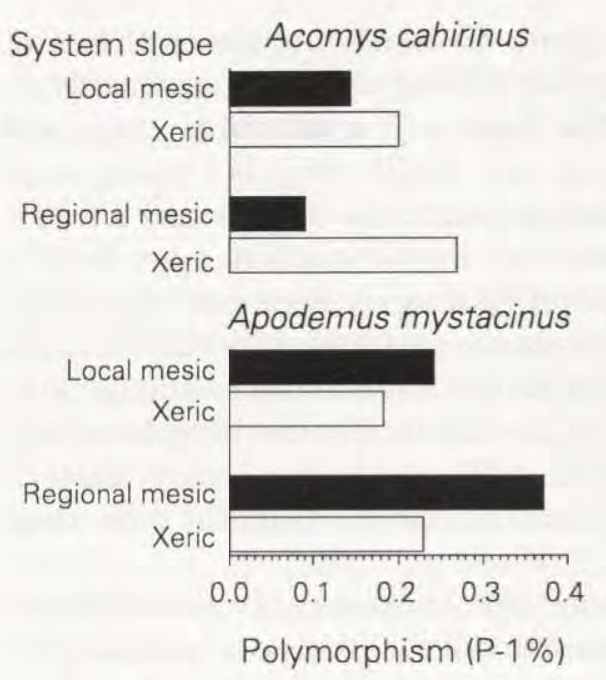

Fig. 3. Local and regional comparison of genetic polymorphism $(\mathrm{P}-1 \%)$ of Acomys cahirinus (mesic population, Hurfesh; xeric population, Timna; both in Nevo 1985) and Apodemus mystacinus (mesic-Galilee Mts.; "xeric" - Judean Mts, Jerusalem, both in Filippucci et al. 1989). The local estimates are from "Evolution Canyon" (this study).
(Nevo 1989). These two trends reflect a positive correlation of weight with latitude (Bergmann's rule) and a negative correlation of body extremities with latitude (Allen's rule). Colour becomes also lighter southward towards the desert. These regional morphological patterns appear to better adapt Acomys to a progressively increasing heat and drought load (Nevo, 1989). Complementarily, physiological, behavioural and genetic adaptations to increasing aridity were reported regionally across Israel (see later) (Fig. 3).

The fossil record indicates that $A$. cahirinus is a recent colonizer of the Mediterranean region, dating from the Upper Paleolithic period, some 20000 years ago (Tchernov 1968). Hence, the geographic variation in morphology, physiology, behaviour and genetics must have taken place during a relatively short period of time, when presumably the northern $2 \mathrm{n}=$ 38 speciated from the southern $2 n=36$ (Nevo 1985), by colonizing the Mediterranean region from the desert. This northward colonization, shared by many African taxa (Atlas of Israel 1970 ) is opposite to other rodents, eg, Spalax, which colonized the steppes and northern Negev desert originating in the more mesic north (Nevo 1991), as did Apodemus which colonized only northern and central Israel (Filippucci et al. 1989).

Regional physiological and behavioural adaptations. Physiological adaptation to the environment has been studied in two populations of the common spiny mouse, A. cahirinus, one from the extreme desert (Elat), the other from the Galilee, an area characterized by temperate Mediterranean conditions (Weissenberg and Shkolnik 1994). The resting metabolic rate at thermoneutrality in the Elat animals

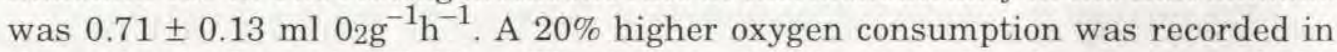
the animals from the Galilee. The lower critical points for the desert and the Galilee animals were $30^{\circ} \mathrm{C}$ and $28^{\circ} \mathrm{C}$, respectively. When measured in the laboratory (ambient temperature $=28^{\circ} \mathrm{C}$ ), the water turnover rate in the Elat animals was $7.14 \pm 1.7 \mathrm{ml}(100)^{-1} \mathrm{day}^{-1}$, and in the animals from the Galilee, 11.22 $\pm 0.45 \mathrm{ml}(100 \mathrm{~g})^{-1} \mathrm{day}^{-1}$. The maximal urine concentration obtained in animals maintained on a high protein, high salt diet was $5663 \pm 737 \mathrm{mosml} / \mathrm{kg}$ in the animals from Elat and $3895 \pm 224 \mathrm{mosmol} / \mathrm{kg}$ in the animals from the Galilee. These results unravel intraspecific geographic variation in metabolism and water 
economy, in accordance with increasing aridity and temperature, and decreasing food productivity (Shkolnik 1988). A resting metabolic rate lower than expected from their body mass is known for many desert rodents (eg Dawson 1955). A low metabolic rate and low water turnover and a lower activity pattern are adaptive in the desert because they imply low rate of heat generation, hence prevent overheating, water expenditure and excessive food requirement (Shkolnik 1988).

Regional genetic adaptations. Genetic adaptations to the regional environmental gradient were also found for Acomys. Allozymic variation encoded by 35 loci was analyzed in specimens from 7 localities involving 2 populations of $A$. cahirinus $2 \mathrm{n}=36$, and 5 populations of $A$. cahirinus $2 \mathrm{n}=38$ (Nevo 1985). The 7 localities represent a general southward transect of increasing aridity from northern Israel to southern Sinai. Polymorphism, $P$, and gene diversity, $H e$, significantly increased southwards with aridity, as was the case in additional 21 unrelated taxa in Israel (Nevo and Beiles 1988), including even subterranean mammals (Nevo et al. 1994). Higher levels of genetic diversity in micro- and macrogeographic spatiotemporally varying environments are effective adaptations to heterogeneous and stressful environment (Nevo 1978, 1988, 1990, 1995, 1998).

\section{Apodemus mystacinus}

Evolutionary biology. The woodmouse A. mystacinus is known from the Balkans, Turkey, Iraq, Syria, Lebanon and Israel (Filippucci et al. 1989). It is frequent in terrace walls, in olive and fig groves, vineyards, orchards and wheat fields, as well as rocky scrubland and Mediterranean maquis. In Israel it is a common species, primarily in Mount Hermon, the Golan Heights, Galilee and the Carmel Mountains and its southern range is around Jerusalem. It is much more restricted in distribution than that of Acomys cahirinus. According to paleontological analysis by Tchernov (1979), three species of Apodemus (A. mystacinus, A. flavicollis and A. sylvaticus) occurred in Israel during the Pleistocene. Moreover, whereas A. mystacinus and A. sylvaticus have been continuously present in this area, A. flavicollis occurred only during colder periods (Tchernov 1979).

The evolutionary biology of the genus Apodemus Kaup 1829 in Israel was studied allozymically and biometrically (Filippucci et al. 1989). The analysis of 36 gene loci, combined with biometric analysis indicated the existence of a new species Apodemus hermonensis on Mt. Hermon at about $2000 \mathrm{~m}$. The most common species in Israel after A. mystacinus is A. flavicollis and not A. sylvaticus as commonly believed. A. flavicollis coexisted in low numbers with A. mystacinus on the NFS of "Evolution Canyon" but it disappeared during recent years from that site, since it was first recorded and apparently fluctuates around the threshold of a very low population density (Blaustein et al. 1996). It is found still elsewhere in Mount Carmel even nearby to "Evolution Canyon" (Hofman and Dolev, unpubl. report, 
1996). The genus Apodemus invaded the Near East, probably from southeastern Europe, relatively late (Tchernov 1979). According to current estimates of evolutionary divergence time from genetic distance data the separation between Israeli and Balkan populations occurred 100000 years ago (Filippucci et al. 1989). A. mystacinus was found in Israel from the Middle Pleistocene; A. sylvaticus appeared in the Upper Levalloise- Mousterian, about 40000 years ago and reached its peak in the Natufian-Neolithic period, about 10000 B.C. (Tchernov 1968, 1979).

On Mount Hermon A. mystacinus ranges with A. flavicollis in the lowest belt $(300-1300 \mathrm{~m})$ characterized by evergreen Mediterranean maquis. In the steppic zone belt above the former (1300-1900 m) only A. mystacinus is present. In the alpine tragacanthic belt above $1900 \mathrm{~m}$ Apodemus is represented only by the new species, A. hermonensis. Elsewhere in Israel the two existing species are primarily A. mystacinus and secondarily (and fluctuating) A. flavicollis (Filippucci et al. 1989).

Regional morphological adaptations. The mean values of body characters for A. mystacinus from six geographic groups of populations (Mount Hermon, Golan Heights, Hula Valley, Tel Dan, Galilee Mountains, Mount Carmel and Judean Mountains) are given in Filippucci et al. (1989; Table II, p. 365). The Golan Heights and Mount Carmel populations showed higher mean values for head and body length (HBL). The population of Mount Hermon showed slightly lower mean values for most body characters. On average, the populations from Mount Hermon, Golan and Jerusalem showed lower mean values of the hind-foot length (HFL). In fact, in these populations average HFL was $24.2<\mathrm{HFL}<24.8$, whereas in those from Galilee and Mount Carmel it was $25.3<\mathrm{HFL}<25.7$. Body weight within Israel increased from the Galilee through Mt. Carmel to Judea (Fig. 3 in Filippucci et al. 1989). This size increase within Israel may derive from the aridity stress on mesic Apodemus from the Galilee to the Judean Mountains rather than thermoregulatory response. On the other hand, the body characters in Israeli groups showed lower mean values than those in Turkey, Lebanon and Syria populations (Lewis et al. 1967), confirming the existence of a clinal variation in $A . m$. mystacinus (Felten et al. 1973), conforming regionally with the Bergmann rule.

Regional genetic adaptations. Regional levels of genetic variation within populations of A. mystacinus appear in Table VII, p. 372 of Filippucci et al. (1989). The overall mean of $A, P 1 \%, H$ and $H e$ were $1.366,0.308,0.04$, and 0.055, respectively. In general these values decrease from the Galilee through Mount Carmel to the Judean Mountains. Likewise, altitudinally, they decrease upwards from low $(300 \mathrm{~m})$ to high $(1200 \mathrm{~m})$ altitude on Mt. Hermon. In other words, genetic diversity of European A. mystacinus decreases in stressful (drier, colder or warmer) environments, close to its species boundaries, both regionally and locally (eg, locally at the SFS in "Evolution Canyon"). This suggests that the genetic strategy of A. mystacinus is opposite to that of A. cahirinus. Under stress regimes its genetic diversity declines, reflecting its more specialist ecological nature. 
The evolutionary driving forces causing genotypic and phenotypic divergence of rodents at "Evolution Canyon"

The genotypic, morphological, physiological and behavioural results obtained at "Evolution Canyon" for both Acomys and Apodemus can not be explained by mutation, migration, stochastic or neutral models. Mutation rate is excluded because of its low rates and the many generations needed for its accumulation by mutation pressure without any selective advantage of the mutants. Migration is ruled out as explanatory model on two grounds, experimental and theoretical. First, mark-recapture data indicated that individual rodents tended to remain largely within the same or the adjacent elevetional location within the same slope. We did not recover a single marked animal on the opposite slope (Blaustein et al. 1996). Presumably, as is true in other organisms studied at "Evolution Canyon", even in flying Drosophila (Nevo et al. 1998) interslope migration is very limited (Nevo 1995, 1997). Second, the interslope genetic divergence suggest that migration which is a homogenizing rather than heterogenizing force, does not play a major role in either genotypic or phenotypic inter- and intraslope differentiation, as is indicated by slope-specific alleles and gametic phase disequilibria (see results).

Stochasticity is ruled out as an explanatory model because the local interslope mesic-xeric divergence largely parallels genotypically and phenotypically the regional mesic-xeric pattern across Israel. This parallelism suggest that macroand microclimatic diversifying selection is a major differentiating force of both genotypes and phenotypes which lead to complex inter- and intraslope adaptive complexes contributing to fitness.

The rodent results discussed here complement biodiversity and genetic diversity results on phenotypes and genotypes at "Evolution Canyon" in diverse groups of organisms across phylogeny, including cyanobacteria, plants, earthworms, landsnails, scorpions, beetles, ants, fruit flies, reptiles and birds [Nevo 1995, 1997 and a series papers in Israel Journal of Zoology 42 (4), 1996]. The results across life involves both species richness, phenotypic and genotypic adaptations. The latter include interslope adaptive complexes in germination pattern in wild barley (Gutterman and Nevo 1994), temperature preference, drought resistance and longevity in Drosophila (Nevo et al. 1998), mutation rate in the fungus Sordaria fimicola (Lamb et al. 1998), and desiccation tolerance in landsnails (Arad 1993, Rankevich et al. 1996). In the rodents themselves, while no interslope gene flow appears to operate, within slope interannual and spatiotemporal rodent adaptive dynamics (Blaustein et al. 1996) and predation (Broza and Nevo 1994) were distinct. Thus, adaptive patterns both in the plants and animals tested suggest that natural selection overrides migration which is presumably selected against even in locomotory (rodent) and flying (eg Drosophila) animals. Transplant experiments in wild barley support these results demonstraing slope-adaptations and fitness (Lavie et al. 1993).

"Evolution Canyon" is a rich evolutionary model appropriate for unfolding adaptive patterns and regularities across life and organizational levels (Nevo 1995, 
1997). Similar, convergent adaptive patterns have been shown earlier locally (Nevo 1988, 1998), regionally (Nevo and Beiles 1988) and globally (Nevo et al. 1984). The advantage of studying contrasting patterns at "Evolution Canyon" lies in displaying global biodiversity patterns and ongoing adaptive evolution in action on a local scale across life's diversity and organization. The single key factor leading to a whole interslope microclimatic differential syndrome is the differential stress of solar radiation. Interslope migration appears to be low not only in sedentary organisms but also in moving organisms such as Drosophila and mice. Effective population sizes of most tested species (more than 1600 species studied todate) are either absolutely or relatively large, hence small size stochastic population effects may be negligent. Likewise, migration can be ruled out as a major evolutionary force because it can not generate the observed phenomena.

The available evidence suggests that microclimatic diversifying natural selection seems to be the major evolutionary force causing adaptive differentiation of genotypes and phenotypes in rodents and other organism between and within slopes. We now plan additional transplant, genetic experiments and genetic mapping to assess adaptive fitness components of some model organisms to the contrasting slopes. "Evolution Canyon" proves an optimal microscale ecological model for unfolding a long-term (several millions of years) evolution in action across life and organization.

Acknowledgements: This work was supported by the Ministry of Science grants nos. 1426 and 4147 the latter with the GSF-Forschungszentrum für Umwelt and Gesundheit GMBH, Neuherberg; the Israeli Discount Bank Chair of Evolutionary Biology, and the Ancell-Teicher Research Foundation for Genetics and Molecular Evolution.

\section{References}

Arad Z. 1993. Effect of desiccation on the water economy of terrestrial gastropods of different phylogenetic origins: A prosobranch (Pomatias glaucus) and two pulmonates (Sphincterochila cariosa and Helix engaddensis). Israel Journal of Zoology 39: 95-104.

Atlas of Israel. 1970. Jerusalem: Ministry of Labour and Amsterdam: Elsevier Publishing Company.

Blaustein L., Kotler B. P. and Nevo E. 1996. Rodent species diversity and microhabitat use along opposing slopes of a Mediterranean microsite: Lower Nahal Oren, Mount Carmel, Israel. Israel Journal of Zoology 42: 327-334.

Broza M. and Nevo E. 1994. Selective land snail predation by the spiny mouse, Acomys cahirinus, in Nahal Oren, Mt. Carmel Israel. Israel Journal of Zoology 40: 173-176.

Cavalli-Sforza L. L. and Edwards A. W. F. 1967. Phylogenetic analysis: models and estimation procedures, Evolution 21: 550-570.

Clark A. G. and Lanigan C. M. S. 1993. Prospects for estimating nucleotide divergence with RAPDs. Molecular Biology and Evolution 10: 1096-1111.

Clegg M. T., Kidwell J. F., Kidwell M. G. and Daniel N. J. 1976. Dynamics of correlated genetic system. I. Selection in the region of the glued locus Drosophila melanogaster. Genetics 83: 793-810.

Cottle H. J. 1932. Vegetation on north and south slopes of mountains in S.E. Texas. Ecology 13: $121-134$. 
Dawson W. R. 1955. The relation of oxygen consumption to temperature in desert rodents. Journal of Mammalogy 36: 543-553.

Felten H., Spitzenberger F. and Storch G. 1973. Zur Kleinesaügerfauna West-Anatoliens. Teil II. Senckenbergiana Biologica 54: 227-290.

Filippucci M. G., Nascetti G., Capanna E. and Bullini L. 1987. Allozyme variation and systematics of European moles of the genus Talpa (Mammalia, Insectivora). Journal of Mammalogy 68: 487-499.

Filippucci M. G., Simson S. and Nevo E. 1989. Evolutionary biology of the genus Apodemus Kaup, 1829 in Israel. Allozymic and biometric analyses with description of a new species: Apodemus hermonensis (Rodentia, Muridae). Bolletino Zoologico 56: 361-376.

Gorman G. C. and Renzi J., Jr 1979. Genetic distance and heterozygosity estimates in electrophoretic studies: effects of sample size, Copeia 1979: 242-249.

Gutterman Y. and Nevo E. 1994. Temperatures and ecological-genetic differentiation affecting the germination of Hordeum spontaneum caryopses harvested from three populations: the Negev Desert and opposing slopes on Mediterranean Mount Carmel. Israel Journal of Plant Sciences 42 : $183-195$.

Holland I. B. 1983. Basic cloning techniques: Course manual. University of Leicester, Leicester

Karcz Y. 1959 The structure of the northern Carmel. Bulletin Research Council of Israel 8G: 119-130.

Kimura M. 1983. The neutral theory of molecular evolution. Cambridge University Press, Cambridge: $1-367$.

Lamb B. C., Saleem M. and Nevo E. 1998. Environment-related genetic variation in mutation frequencies in Sordaria over a microscale, in "Evolution Canyon". Genetics 149: 87-99.

Lavie B., Stow V., Krugman T., Beiles A. and Nevo E. 1993. Fitness in wild barley from two opposing slopes of a Mediterranean microsite at Mount Carmel, Israel. Barley Genetics Newsletter 23: $12-14$.

Lewis R. E., Lewis J. H., and Atallah S. 1. 1967. A review of Lebanese mammals. Lagomorpha and Rodentia. Journal of Zoology 153: 45-70.

Lynch M. and Milligan B. G. 1994. Analysis of population genetic structure with RAPD markers. Molecular Ecology 3: 91-99.

Nei M. 1978. Estimation of average heterozygosity and genetic distance from a small number of individuals. Genetics 89: 583-590.

Nevo E. 1978. Genetic variation in natural populations: Patterns and theory. Theoretical Population Biology 13: 212-177.

Nevo E. 1985. Genetic differentiation and speciation in spiny mouse, Acomys. Acta Zoologica Fennica 170: $131-136$.

Nevo E. 1988. Genetic diversity in nature: Patterns and theory. Evolutionay Biology 23: 217-246.

Nevo E. 1989. Natural selection of body size differentiation in spiny mice, Acomys. Zeitschrift für Säugetierkunde 54: 81-99.

Nevo E. 1990. Molecular evolutionary genetics of isozymes: Patterns, theory and application. [In: Isozymes: Structure, function and use in biology and medicine. Z.-I. Ogita and C. L. Markert, eds]. Wiley Liss, Inc.: 701-742.

Nevo E. 1991. Evolutionary theory and processes of active speciation and adaptive radiation in subterranean mole rats, Spalax ehrenbergi superspecies in Israel. Evolutionary Biology 25: 1-125.

Nevo E. 1994. Biodiversity: The "Evolution Canyon" at Nahal Oren, Mt. Carmel, Israel. Israel Journal of Botany 42: 83 (abstract).

Nevo E. 1995. Asian, African and European biota meet at "Evolution Canyon", Israel: Local tests of global biodiversity and genetic diversity patterns. Proceedings of the Royal Society London B 262: $149-155$.

Nevo E. 1997. Evolution in action across phylogeny caused by microclimatic stresses at "Evolution Canyon". Theoretical Population Biology 52: 231-243.

Nevo E. 1998. Molecular evolution and ecological stress at global regional and local scales: The Israeli perspective. Journal of Experimental Zoology 282: 95-119. 
Nevo E. and Beiles A. 1988 Genetic parallelism of protein polymorphism in nature: Ecological test of the neutral theory of molecular evolution. Biological Journal of Linnean Society 35: 229-245.

Nevo E., Beiles A. and Ben-Shlomo R. 1984 The evolutionary significance of genetic diversity: Ecological, demographic and life history correlates. Lecture Notes in Biomathematics 53: 13-213.

Nevo E., Ben-Shlomo R., Beiles A., Ronin Y., Blum S. and Hillel J. 1996. Genomic adaptive strategies: DNA fingerprints reveal ecogenetic parallelism to allozymes, RAPDs, mitochondrial DNA, and chiasma frequency in the actively speciating mole rats in Israel. In: Gene families: Structure, function, genetics and evolution. R. S. Holmes and H. A. Lim, eds]. World Scientific, New Jersey: $55-70$.

Nevo E., Filippucci M. G. and Beiles A. 1994. Genetic polymorphisms in subterranean mammals (Spalax ehrenbergi superspecies) in the Near East revisited: Patterns and theory. Heredity 72 : 465-487.

Nevo E., Perl T., Beiles A. and Wool D. 1981. Mercury selection of allozyme genotypes in shrimps. Experientia 37: 1152-1154

Nevo E., Rashkovetsky E., Pavlicek T. and Korol A. 1998. A complex adaptive syndrome in Drosophila caused by microclimatic contrasts. Heredity 80:9-16.

Ohta T. and Tachida H. 1990. Theoretical study of near neutrality. I. Heterozygosity and rate of mutant substitution. Genetics 126: 219-229.

Rankevich D., Lavie B., Nevo E., Beiles A. and Arad Z. 1996. Genetic and physiological adaptations of the prosobranch landsnail Pomatias olivieri to microclimatic stresses on Mt. Carmel, Israel. Israel Journal of Zoology 42: 425-441.

Sarich V. M. 1977. Rates, sample sizes and the neutrality hypothesis for electrophoresis in evolutionary studies. Nature 263: 24-28.

Shkolnik A. 1988. Physiological adaptations to the environment: the Israeli experience. (In: The zoogeography of Israel. Y. Yom-Tov and E. Tchernov, eds]. Dr W. Junk Publishers, The Hague, Netherlands: $487-496$.

Shkolnik A. and Borut A. 1969. Temperature and water relations in two species of spiny mice (Acomys). Journal of Mammalogy 50: 245-255.

SPSS. 1990. SPSS Reference Guide, Release 4. Chicago: SPSS Inc.

Swofford D. L. and Selander R. B. 1989. Manual of Biosys-1 Computer Program, Release 1.7. Distributed by D.L. Swofford, Illionoi's Natural History Survey.

Tchernov E. 1968. Succession of rodent faunas during the Upper Pleistocene of Israel. Verlag Paul Parey, Hamburg and Berlin: 1-152.

Tchernov E. 1979. Polymorphism, size trends and Pleistocene paleoclimatic response of the subgenus Sylvaemus (Mammalia, Rodentia) in Israel. Israel Journal of Zoology 28: 131-159.

Van Valen L. 1965. Morphological variation and width of ecological niche. American Naturalist 99 $377-390$

Wahrman J. and Goitein R. 1972. Hybridization in nature between two chromosome forms of spiny mice. Chromosomes Today 2: 228-237.

Weissenberg S. and Shkolnik A. 1994. Metabolic rate and water economy in the desert and Mediterranean populations of the common spiny mouse (Acomys cahirinus) in Israel. Israel Journal of Zoology 40: 135-143.

Williams J. G. K., Rubelik A. R., Livak K. J., Rafalski J. A. and Tingey S. V. 1990. DNA polymorphism amplified by arbitrary primers are useful as genetic markers. Nucleic Acid Research 18: $6531-6535$.

Received 25 May 1998, accepted 30 June 1998 